Georgetown University Law Center

Scholarship @ GEORGETOWN LAW

2018

Interpretation and Construction in Contract Law

Gregory Klass

Georgetown University Law Center, gmk9@law.georgetown.edu

This paper can be downloaded free of charge from:

https://scholarship.law.georgetown.edu/facpub/1947

https://ssrn.com/abstract=2913228

This open-access article is brought to you by the Georgetown Law Library. Posted with permission of the author. Follow this and additional works at: https://scholarship.law.georgetown.edu/facpub

Part of the Contracts Commons 


\section{Interpretation and Construction in Contract Law}

Gregory Klass*

January 2018 - DRAFT

When faced with questions of contract interpretation, courts commonly begin with the principle that " $[\mathrm{t}]$ he primary goal in interpreting contracts is to determine and enforce the parties' intent." ${ }^{11}$ The maxim affirms that contractual obligations are chosen obligations. Parties acquire them by voluntarily entering into agreements whose terms they control. Contract interpretation therefore begins by seeking out the choices parties made. The maxim is of a piece with a picture of contract as a form of private legislation. Contract law gives parties the power to undertake new legal obligations when they wish. That power requires giving parties the obligations they intend. And the maxim serves to allocate responsibility. When a court enforces a contract, it is not imposing an obligation on a party, but merely giving effect to her own earlier choice. If a party is now unhappy with the contract terms, she has only her earlier self to blame.

But of course contractual obligations are not only a matter of party choice or intent. Sometimes when parties enter into the agreement, they do not have or do not express an intent one way or another on some issuessay whether the seller warrants the quality of the goods or the remedy for breach. Thus the importance of default rules in contract law, which determine parties' contractual obligation in the absence of evidence of their intent. Alternatively, the parties' expressions of their intent might be ambiguous. When this occurs, a court might apply a rule like contra proferentem, interpreting against the drafter, or the preference for

\footnotetext{
*Agnes N. Williams Research Professor, Professor of Law, Georgetown University Law Center. I am grateful to John Mihail, Ralf Poscher and especially Lawrence Solum for helpful comments on earlier drafts.

${ }^{1}$ Old Kent Bank v. Sobczak, 243 Mich. App. 57, 63 (2000). A few other examples: "The fundamental, neutral precept of contract interpretation is that agreements are construed in accord with the parties' intent." Greenfield v. Philles Records, Inc., 98 N.Y.2d 562, 569 (2002). "Under statutory rules of contract interpretation, the mutual intention of the parties at the time the contract is formed governs interpretation." AIU Ins. Co. v. Superior Court, 51 Cal. 3d 807, 821 (1990) (citing Cal. Civ. Code $\S 1636$ ). "The cardinal rule for interpretation of contracts is to ascertain the intention of the parties and to give effect to that intention, consistent with legal principles." Bob Pearsall Motors, Inc. v. Regal Chrysler-Plymouth, Inc., 521 S.W.2d 578, 580 (Tenn. 1975).
} 
interpretations in the public interest, neither of which looks to party intent. There are also cases in which the parties' intent is clear, but a court will decline to give it legal effect. This is so when their agreement runs contrary to a mandatory rule, such as minimum wage or civil rights laws, the penalty rule, or the more general prohibition on enforcing agreements against public policy. Courts also often apply interpretive rules that predictably sometimes fail to capture what the parties actually intended. Plain meaning rules, for example, exclude context evidence that can be essential for understanding the parties' intent. Finally, "the parties' intent" is itself ambiguous. Does it refer to parties' intent with respect to their legal obligations? Or does it refer only to their intended exchange, from which those legal obligations flow?

In order to understand the relationship between parties' expressions of intent and their contractual obligations, one needs to distinguish two activities: interpretation and construction. Interpretation identifies the meaning of words or actions, construction their legal effect. Legal interpretation employs linguistic and other social abilities that originate outside the law. To live in a social world means to be constantly interpreting the words and actions of others. We interpret what people say, both expressly and by implication; the reasons for their actions; their beliefs and their intentions. Legal interpretation engages those interpretive skills, though it sometimes shackles them in one way or another. Rules of construction, in distinction, originate in the law. Rules of construction translate the output of interpretation into legal effects. Rules of construction therefore govern the relationship between the ordinary and the legal meanings of parties' words and actions, or between the parties' intent and their contractual obligations.

Although the distinction between interpretation and construction is easy to state in the abstract, a complete account of the two activities and the relationship between the two is no easy thing — even if one restricts the inquiry to interpretation and construction in contract law. ${ }^{2}$ One reason is that contract interpretation takes several different forms. Depending on the details of the transaction and the legal question at issue, it might aim at the plain meaning of the parties' words, at those words' contextually determined use meaning, at subjective or at objective meaning, at an agreement's apparent purpose or purposes, or at what the parties believed or intended. Rules of contract construction also come in several varieties. They include the familiar categories of mandatory and default rules, as well

${ }^{2}$ The interpretation-construction distinction has recently received considerable attention from constitutional theorists, and especially originalist. See, e.g., Lawrence B. Solum, The Interpretation-Construction Distinction, 27 Const. Comment. 95 (2010); Randy Barnett, Interpretation and Construction, 34 Harv. J.L. \& Pub. Pol'y 65 (2011); Jack M. Balkin, The New Originalism and the Uses of History, 82 Fordham L. Rev. 641 (2013). 
as the less familiar category of altering rules-rules that govern when parties words or actions suffice to contract out of a default legal state of affairs. And while some altering rules require interpretation of the parties' words and actions, others employ formalities that need no interpretation. Finally, the relationship between the activities of interpretation and construction is itself complex. In the order of application, interpretation comes first, construction second. One must often interpret the parties' words before one can determine their legal effect. But because legal interpretation is always in the service of construction, the correct approach to legal interpretation depends on the applicable rule of construction. And rules of construction sometimes affect the meaning of what parties sayboth because acts of judicial construction can give words new conventional legal meanings and because parties often intend their words to have certain legal effects.

This Article provides a descriptive theory of interpretation and construction in the law of contracts and the interplay between the two activities. ${ }^{3}$ Part One traces the history of the concepts in US law and legal theory, which provides the basis for a clearer understanding of each. The history focuses on three figures: Francis Lieber, Samuel Williston and Arthur Linton Corbin. Tracing the development of the concepts of interpretation and construction through these three authors suggests two different conceptions of them. In both Lieber and Williston, one finds a supplemental conception of interpretation and construction. For both, construction appears only when interpretation either runs out due to gaps or ambiguity or gaps or runs up against a higher-order rule. Corbin, in distinction, articulates a complementary conception of the two activities. According to Corbin, rules of construction apply throughout the process of contract exposition, operating also in the absence of gaps or ambiguities. Part One argues that the complementary conception provides the better theoretical account of the two distinct activities.

Part Two provides a systematic account of the rules of contract construction. Rules of construction include mandatory rules, default rules and altering rules. Over the past thirty years, contract theorists have had much to say about both mandatory and default rules. They have paid less systematic attention to altering rules, which govern what it takes to change

${ }^{3}$ Although Keith Rowley and Edwin Patterson each refer to the distinction between interpretation and construction in the title of an article, those works do not provide analyses of the distinction itself. See Keith A. Rowley, Contract Construction and Interpretation: From the "Four Corners" to Parol Evidence (and Everything in Between), 69 Miss. L.J. 73 (1999); Edwin W. Patterson, The Interpretation and Construction of Contracts, 64 Colum. L. Rev. 833 (1964). 
a default legal state of affairs. ${ }^{4}$ Part Two describes the structure of contract altering rules and provides a typology of them. Altering rules determine among other things what types of meaning are legally salient, and thereby also how the parties' words and actions should be interpreted.

The description of altering rules provides the groundwork for Part Three's discussion of contract interpretation. The rules of contract construction call on several different types of meaning. These include plain meaning, use meaning, subjective meaning, objective meaning, purpose, and belief and intent. The correct approach to contract interpretation differs according to the facts of the case and the legal question at issue.

Part Four examines the interplay between interpretation and construction. Because legal actors often take account of the law when deciding what to say and do, interpreting their words and actions sometimes requires understanding the rules of construction they mean to satisfy or avoid. I term this the "pragmatic priority" of construction. Official acts of construction can also give words or entire clauses technical meanings, turning them into legal terms of art. This I call the "semantic priority" of construction. Consequently, whereas interpretation typically precedes construction in the order of exposition, there instances in which the interpreter must know the legal rule of construction in order identify the meaning of the parties' words or actions. The law of contract is designed to take advantage of this interplay.

Before proceeding further, a few words about method. This Article is about the structure and content of legal rules. My interest is therefore in the legally authorized activities of interpretation and construction. When I say that interpretation precedes construction in the process of exposition, I am saying something about the relevant legal rules. This is not to say that parties, judges or other legal actors always play by those rules. Legal actors, consciously or unconsciously, sometimes look to results before rules. And the rules themselves are loose enough to allow some play at the joints. Thus Corbin, ever the Legal Realist, observed:

Just as construction must begin with interpretation, we shall find that our interpretation will vary with the construction that must follow. Finding that one interpretation of the words will be followed by the enforcement of certain legal effects, we may back hastily away from that interpretation and substitute another that will lead to a more desirable result. ${ }^{5}$

\footnotetext{
${ }^{4}$ The first attempt at a systematic account of altering rules can be found in Ian Ayres, Regulating Opt-Out: An Economic Theory of Altering Rules, 121 Yale L.J. 2032 (2012).

${ }^{5}$ Arthur Linton Corbin, 3 Corbin on Contracts: A Comprehensive Treatise on the Rules of Contract Law $\S 534$ at 11 (1951) (hereinafter "Corbin (1st ed.)"). Eyal Zamir makes a similar point in The Inverted Hierarchy of
} 
This is an enormously important point, not in the least because the ability to substitute an interpretation that will lead to a more desirable result suggests that meaning is, to some degree and in some cases, indeterminate. The determinacy or indeterminacy of meaning has long been a topic of discussion and disagreement among legal theorists. ${ }^{6}$ And the degree to which legal texts have stable, predictable and precise meanings is crucial to the justification and critical appraisal of rules of construction that take one or another form of meaning as their starting points.

That said, this Article is about the internal logic of legal rules that assume that words and other legally relevant acts often have sufficiently determinate meanings to bind future actors. From that point of view, outcome driven forms of interpretation are ultra vires. They do not belong to the internal logic of the law. This is not to say that they are not interesting or important. Only that they are not my topic here.

\section{The Interpretation-Construction Distinction}

Like all concepts, the ideas of interpretation and construction have a history. This Part traces the distinction from its origin in the work of Francis Lieber to the first edition of Samuel Williston's treatise, and then on to the first edition of Arthur Linton Corbin's treatise. That history shows a movement from a supplemental conception of interpretation and construction, according to which interpretation alone can answer some legal questions, to a conception of the two activities as complementary, according to which a rule of construction must always be applied to arrive at a legal result. I argue that the complementary conception of the distinction is the descriptively correct and more theoretically productive one.

\subsection{Francis Lieber}

The interpretation-construction distinction is commonly traced to Francis Lieber's 1839 book, Legal and Political Hermeneutics, or Principles of Interpretation and Construction in Law and Politics, ${ }^{7}$ though Ralf Poscher

Contract Interpretation and Supplementation, 97 Colum. L. Rev. 1710 (1997).

${ }^{6}$ See, e.g., Gary Peller, The Metaphysics of American Law, 73 Cal. L. Rev. 1151 (1985); Lawrence B. Solum, On the Indeterminacy Crisis: Critiquing Critical Dogma, 54 U. Chi. L. Rev. 462 (1987).

${ }^{7}$ Francis Lieber, Legal and Political Hermeneutics, or Principles of Interpretation and Construction in Law and Politics (enlarged ed. 1839/1970). The book is a reworking and expansion of two articles that appeared in The American Jurist in 1837 and 1838. 
has suggested that Lieber's approach is rooted in Friedrich Schliermacher's earlier work on hermeneutics. ${ }^{8}$

Lieber understands successful communication to be the transmission of ideas from one person to another through the use of words or other signs. Interpretation is the activity of discovering those ideas. "Interpretation is the art of finding out the true sense of any form of words: that is, the sense which their author intended to convey, and of enabling others to derive from them the very same idea which the author intended to convey. ${ }^{\prime 9}$ Lieber suggests that with respect to authoritative legal texts, successful interpretation suffices to identify the text's legal effect, which is the effect intended by the authority that authored or authorized that text. Although Lieber does not articulate a command theory of law, this account of interpretation is consistent with one. ${ }^{10}$ The correct interpretation of a command identifies the intent of the authority who issued it-precisely how Lieber describes the correct interpretation of a legal text.

Lieber observes that sometimes interpretation alone is not enough to identify what the law is. In the course of Legal and Political Hermeneutics, he identifies several situations in which the "true significance," of a legal text might not fully determine what the associated law is: (1) when the text contains internal contradictions; ${ }^{11}(2)$ "in cases which have not been foreseen by framers of those rules, by which we are nevertheless obliged, for some binding reason, faithfully to regulate, as well as we can, our

${ }^{8}$ Ralf Poscher, The Hermeneutical Character of Legal Construction, in Law's Hermeneutics: Other Investigations 207, 207 (Simone Glanert and Fabien Girard eds., 2017).

${ }^{9}$ Lieber, supra note 7 at 23.

${ }^{10}$ See H.L.A. Hart, The Concept of Law 18-25 (2d ed. 1994); H.L.A. Hart, Commands and Authoritative Legal Reasons, in H.L.A. Hart, Essays on Bentham: Studies in Jurisprudence and Political Theory 243-268 (1982). ${ }^{11}$ Lieber, supra note 7 at 55-56. Today many theorists would also say that construction is necessary when a legal text is ambiguous. Lieber's intentbased understanding of meaning, however, leads him to conclude that a legal text cannot be ambiguous.

No sentence, or form of words, can have more than one 'true sense,' and this only one we have to inquire for. . . Every man or body of persons, making use of words, does so, in order to convey a certain meaning; and to find this precise meaning is the object of all interpretation. To have two meanings in view is equivalent to having no meaning-and amounts to absurdity. Even if a man use words, from kindness or malice, in such a way, that they may signify one or the other thing, according to the view of him to whom they are addressed, the utterer's meaning is not twofold; his meaning is simply not to express his opinion.

Id. at 86 . 
actions respecting the unforeseen case" $;^{12}$ and (3) when the simple meaning of the text contravenes "more general and binding rules, [such as]

constitutional, written and solemnly acknowledged rules, or moral ones, written in the heart of every man. ${ }^{\prime 13}$ In each of these instances, interpretation alone cannot determine the legal outcome.

Lieber does not discuss contracts, but contract law includes rules that address each of the situations Lieber identifies. The Mirror Image Rule and section 2-207 of the Uniform Commercial Code (UCC), for example, each provides a rule to resolve potentially authoritative but conflicting contractual texts. Under the Mirror Image Rule, the terms in last document sent control (the "last shot rule"). ${ }^{14}$ Under section 2-207, conflicting terms drop out entirely and are replaced by Article Two's default terms. ${ }^{15}$ In neither case does the rule turn on further interpretation of the meaning of the parties' words or intentions. Lieber's second category, "cases which have not been foreseen by the framers," describes both situations that trigger contractual defaults and the implied duty of good faith. Defaults apply when a contractual agreement is silent on a subject-when, in effect, the parties have not agreed on a relevant term. ${ }^{16}$ The implied duty of good faith constrains a party's actions when a contractual agreement gives her discretion or does not fully specify her obligations, often due to unforeseen circumstances. ${ }^{17}$ Finally, the doctrines of unconscionability and public policy both generate cases in which a text's legal effect is limited by "more general and binding rules." ${ }^{18}$

In each of these situations interpretation alone fails to specify the correct legal rule. We require supplemental rules or principles to determine the legal state of affairs. Lieber terms these rules of "construction."

\section{${ }^{12} / d$. at 56.}

${ }^{13} / d$. at 166. Or again: "But it is not said that interpretation is all that shall guide us, and ... there are considerations, which ought to induce us to abandon interpretation, or with other words to sacrifice the direct meaning of a text to considerations still weightier; especially not to slaughter justice, the sovereign object of laws, to the law itself, the means of obtaining it." Id. at 115.

${ }^{14}$ See E. Allan Farnsworth, Contracts $\S 3.21$ (4th ed. 2004).

${ }^{15}$ The above statement of the section 2-207 rule for different terms oversimplifies, but is in the author's opinion the best reading of this poorly drafted statute. See 2 Anderson U.C.C. §§ 2-207:102 \& 103 (3d. ed.). Other readings of section 2-207 provide alternative rules of construction for cases in which writings conflict.

${ }^{16}$ See, e.g. U.C.C. $\S \S 312,314$ \& 315 (implied warranties of title, merchantability and fitness).

${ }^{17}$ See Daniel Markovits, Good Faith as Contract Law's Core Value, in Philosophical Foundations of Contract Law 272 (G. Klass, et al. eds., 2014).

${ }^{18}$ See Restatement (Second) of Contracts $\S \S 178-185,208$ (1981). 
In politics, construction signifies generally the supplying of supposed or real imperfections, or insufficiencies of a text, according to proper principles and rules. By insufficiency, we understand, both imperfect provision for the cases, which might or ought to have been provided for, and the inadequateness of the text for cases which human wisdom could not foresee. ${ }^{19}$

Construction is unavoidable because "[m]en who use words, even with the best intent and great care as well as skill, cannot foresee all possible complex cases, and if they could, they would be unable to provide for them, for each complex case would require its own provision and rule." ${ }^{\prime 20}$

Construction for Lieber therefore serves a gap-filling and equitable function. On Lieber's theory, "interpretation precedes construction" because construction steps in when interpretation runs out or runs up against a higher-order legal rule or principle. ${ }^{21}$ For this reason, Lieber also sees a continuity of purpose between the two activities. "Construction is the drawing of conclusions respecting subjects, that lie beyond the direct expression of the text, from elements known from and given in the textconclusions which are in the spirit though not within the letter of the text." ${ }^{22}$ This supplemental conception suggests that, at least when extending a legal text to unforeseen cases, one should look for parallels covered cases. "Construction is the building up with given elements, not the forcing of extraneous matter into a text." ${ }^{23}$ That said, Lieber recognizes that to arrive at the correct legal rule it is sometimes necessary to go beyond the "spirit" of the text. This is so when construction is required to cure some injustice in the law or conform it to a superior authority, as when a statute is construed to conform to constitutional requirements. ${ }^{24}$

The most interesting feature of Lieber's theory for the analysis that follows is this supplemental conception of interpretation and construction. Lieber describes construction as operating only in what Larry Solum calls the "construction zone": "the zone of underdeterminacy in which construction that goes beyond direct translation of semantic content into

${ }^{19} / d$. at 57.

${ }^{20}$ Id. at 121.

21 "Since our object is to discover the sense of the words before us, we must endeavor to arrive at it as much as possible from the words themselves, and bring to our assistance extraneous principles, rules, or any other aid, in that measure and degree, only as the strictest interpretation becomes difficult or impossible, (interpretation precedes construction) otherwise interpretation is liable to become predestined." Id. at 113.

${ }^{22}$ Id. at 56.

${ }^{23}$ Id. at 124 .

${ }^{24}$ Id. at 58-59. 
legal content is required for application" of the rule. ${ }^{25}$ According to Lieber's supplemental conception, construction steps in when interpretation fails to determine the text's legal effect. ${ }^{26}$

\subsection{Samuel Williston}

It would be interesting to trace the influence of Lieber's distinction between interpretation and construction throughout the next century of legal thought. Poscher suggests that it appears in somewhat different guise in Friedrich von Savigny's 1840 System of Modern Law. ${ }^{27}$ William Story employs the categories in his 1844 A Treatise on the Law of Contracts Not under Seal, as does Theophilus Parsons in his 1855 Law of Contract. ${ }^{28}$ Lieber's distinction also appears in the 1868 first edition of Thomas Cooley's treatise on the US Constitution, the same year Lieber's concepts first appeared in John Bouvier's legal dictionary. ${ }^{29}$ James Bradley Thayer, in his 1898 Treatise on Evidence, expressly declines to adopt the distinction, arguing that "neither common usage nor practical convenience in legal discussions support [it]," and the concepts do not appear in Wigmore's 1905 or 1923 discussions of interpretation. ${ }^{30}$ For my purposes, things become interesting with the 1920 first edition of Samuel Williston's The Law of Contracts. In section 602, "Construction and interpretation," Williston makes what I view as two improvements on Lieber's theory.

${ }^{25}$ Solum, supra note 2 at 108 (2010) (internal punctuation omitted).

${ }^{26}$ What I am calling the "supplemental conception" is akin to what Solum calls the "Alternative Methods Model." Lawrence B. Solum, Originalism and Constitutional Construction, 82 Fordham L. Rev. 453, 498-99 (2013).

${ }^{27}$ Poscher, supra note 8 at 207.

${ }^{28}$ William W. Story, A Treatise on the Law of Contracts Not under Seal, § 228, at 148 (1844); 2 Theophilus Parsons, The Law of Contracts 3 n. a (1855); 4 John Henry Wigmore, A Treatise on the System of Evidence in Trials at Common Law, §§ 2458-2478 (1905); 5 John Henry Wigmore, A Treatise on the Anglo-American Law of Evidence in Trials at Common Law, $\S \S 2458-2478$ (2d ed. 1924).

${ }^{29}$ Thomas M. Cooley, Treatise on the Constitutional Limitations which Rest upon the Legislative Power of the States of the American Union 89 n. 1 (1868); John Bouvier, A Law Dictionary Adapted to the Constitution and Laws of the United States of America 337 (12th ed. 1868).

${ }^{30}$ James Bradley Thayer, A Preliminary Treatise on The Law of Evidence at the Common Law 411 n. 2 (1898).

John Austin indicates something like Lieber's distinction in his Fragments, where he distinguishes between "[c]onsequences expressed by parties, and consequences annexed by law in default of such expression." John Austin, Fragments - On Contracts, in Lectures on Jurisprudence, or The Philosophy of Positive Law 939 (Robert Campbell ed., 4th ed. 1879). 
First, Williston suggests a narrower conception of construction. The drawing of "conclusions that are in the spirit, though not in the letter of the text," Williston argues, is not different in kind from interpretation and "seems of no legal consequence as far as the law of contracts is concerned." ${ }^{31}$ For example, when a court reads a written agreement "as a whole to determine its purpose and intent," ${ }^{\prime \prime 2}$ it is engaging in a form of interpretation, even when the result supplements or even supplants the literal words in the agreement. ${ }^{33}$ One must interpret an agreement to determine its purpose and the parties' likely intent. Better then, Williston suggests, to limit "construction" to activities entirely distinct from interpretation. For example, "when it is said that contracts which affect the public are to be construed most favorably to the public interest, it is obvious that the court is no longer applying a standard of interpretation, that is it is not seeking the intention of the parties. ${ }^{\prime 34}$ Similarly when a guarantee is interpreted in favor of the guarantor. Construction, for Williston, is the category of rules whose function is not to realize or extend the parties' intentions, but that serve some other principle or purpose.

Although he advocates a narrower conception of construction, Williston follows Lieber is in conceiving construction as supplemental to interpretation. "[A] rule of construction can come into play only when the primary standard of interpretation leaves the meaning of the contract ambiguous." ${ }^{35}$ Construction again appears only when interpretation runs out.

Williston's second innovation is to suggest that neither interpretation nor construction suffices to determine the legal state of affairs. Each concerns itself "with the legal meaning of the contract, not with its legal effect after that meaning has been discovered." ${ }^{36}$ The legal effect,

${ }^{31}$ Samuel Williston, 2 The Law of Contracts $\S 602,1160$ (1920) (hereinafter "Williston (1 st ed.)").

${ }^{32}$ W.W.W. Assocs., Inc. v. Giancontieri, 77 N.Y.2d 157, 162 (1990).

${ }^{33}$ See, e.g., McCoy v. Fahrney, 55 N.E. 61, 63 (IIl. 1899) ("Particular expressions will not control where the whole tenor or purpose of the instrument forbids a literal interpretation of the specific words.").

${ }^{34}$ Williston (1st ed.) at 1161.

Interestingly, Williston suggests that contra proferentem-the rule that ambiguities are to be interpreted against the drafter-is a rule of interpretation, "since it should be anticipated that the person addressed will understand ambiguous language in the sense most favorable to himself, and that his reasonable understanding should furnish the standard" Id. I would say this is at best a majoritarian rule of construction, and better supported by considerations of fairness and incentives than by the logic of interpretation.

${ }^{35} / d$.

${ }^{36} / d$. 
Williston suggests, is a function of "substantive law of contracts which comes into play after interpretation and construction have finished their work. ${ }^{\prime \prime 7}$ Williston served as the Reporter for the first Restatement of Contracts, and a similar claim appears again in the comments to section 226: "Interpretation is not a determination of the legal effect of language. When properly interpreted it may have no legal effect, as in the case of an agreement for a penalty; or may have a legal effect differing from that in terms agreed upon, as in the case of a common-law mortgage. ${ }^{\prime 38}$

Williston therefore distinguishes three activities: (1) interpretation, which aims to get at the author's intention; (2) a supplemental activity of construction, which applies purely non-interpretive principles and steps in when interpretation runs out, such as in cases of irresolvable vagueness or ambiguity; and (3) the substantive law of contract, which specifies legal effects based on the work of interpretation and construction.

\subsection{Arthur Linton Corbin}

Corbin's 1951 treatise on contract law marks an important step forward in understanding the activities of interpretation and construction. Corbin provides the first clear account of construction as complementing, rather than merely supplementing, interpretation. He describes interpretation and construction as interlocking activities, each of which is necessary to determine what the law is.

By "interpretation of language" we determine what ideas that language induces in other persons. By "construction of the contract," as the term will be used here, we determine its legal operation-its effect upon the action of courts and administrative officials. If we make this distinction, then the construction of a contract starts with the interpretation of its language but does not end with it; while the process of interpretation stops wholly short of a determination of the legal relations of the parties. ${ }^{39}$

${ }^{37} / d$.

${ }^{38}$ Restatement of Contracts $\S \S 226 \mathrm{cmt}$. c (1932).

${ }^{39}$ Corbin (1st ed.) $\S 534$ at 7 . Those interested in the development of Corbin's thoughts on the interpretation-construction distinction should begin with a passage he added on the subject as editor the 1919 third American Edition of Anson's Principles of the Law of Contracts. William Reynell Anson, Principles of the Law of Contract: With a Chapter on the Law of Agency, 14th English ed., 3rd American ed. § 353, 405-06 (Arthur L. Corbin ed. 1919) (reprinted in Arthur L. Corbin, Conditions in the Law of Contract, 28 Yale L.J. 739, 740-41 (1919)). 
Whereas Williston distinguished between, on the one hand, legal rules that resolve ambiguities or fill gaps and, on the other, rules that determine the legal effect of an unambiguous text or other speech act, Corbin recognizes that those two activities are not different in kind. Both determine the legal effect of what the parties said and did, including what they did not say or do. Both should therefore be classified as rules of construction.

This more expansive view of construction-the activity of determining the legal effect of a legal actor's words and actions-allows Corbin to view construction as complementing, rather than supplementing, interpretation. ${ }^{40}$ Both Lieber and Williston conceived of construction as stepping in only when interpretation runs out. Corbin suggests that determining the parties' contractual obligation always requires a rule of construction. ${ }^{41}$ "[T] he process of interpretation stops wholly sort of a determination of the legal relations of the parties," because interpretation tells us only what some persons said, meant or intended. We require a rule of construction, or what H.L.A. Hart called a "rule of change," 42 to determine which sayings or meanings or intendings of what legal actors have what legal effects.

Suppose, for example, an unemancipated minor and an adult each signs an identical enforceable agreement, each clearly evincing her intention that it be binding. Under US law, only the adult thereby acquires a nonvoidable contractual obligation. ${ }^{43}$ The agreements and signatures have the same meaning; but meaning alone does not determine legal effect. That requires a rule of construction. Here the relevant rule provides that the adult's signature results in a nonvoidable contractual obligation, whereas the same act done by a minor creates an obligation that the minor can later disclaim. Rules of construction determine not only unintended legal consequences, as Lieber and Williston maintain, but also intended ones.

This broader conception of construction casts new light on the maxim that the primary goal of contract interpretation is to ascertain the parties' intent. ${ }^{44}$ Although often treated as a rule of interpretation, the rule is in fact one of construction. It says that when adjudicators are determining contracting parties' legal obligations, they should look first to evidence of the parties' shared intentions. Generally speaking and ceteris paribus, contract law enforces the agreement that the parties intended. Such a rule is a rule of construction.

${ }^{40}$ What I am calling the "complementary conception" of interpretation and construction is similar to what Solum calls the "Two Moments Model."

Solum, Constitutional Construction, supra note 26 at 498-99.

${ }^{41}$ Thus Corbin could expressly reject Lieber's account of interpretation and construction. Corbin (1st ed.) §534, at 11, n.11.

${ }^{42}$ Hart, The Concept of Law, supra note 10 at 95-96.

${ }^{43}$ See Restatement (Second) of Contracts $§ 14$ (1981).

${ }^{44}$ See supra note 1 
But that is only generally speaking. When parties have memorialized their agreement in an integrated writing, for example, their contractual rights and obligations might turn on the writing's plain meaning, even if one or both parties had a different understanding of its content. And other rules of construction-the ones Lieber and Williston emphasize, and that Corbin also discusses-hew even less closely to the parties' expressed intent. Examples include generic rules of construction like contra proferentem and the rule favoring interpretations that accord with public policy. Also in this category are the many default rules that determine parties' legal obligations absent their contrary expression, as well as mandatory rules that parties cannot contract out of, such as the duty of good faith. The rules of contract construction also include rules that deny enforcement based on the substance of an agreement, such as the rules for illegal agreements or the unconscionability doctrine. These and other extrainterpretive rules of construction apply when the object of interpretation is ambiguous, contradictory or gappy, when the situation is one that we believe lawmakers did not foresee, or when the text's meaning or parties' intent contravenes a higher legal authority or principle.

The important point, however, is Corbin's recognition that a text's meaning never suffices to determine its legal effect. Even when the text appears to fully determine the legal rule, it does so only by virtue of a rule of construction. Construction does not supplement interpretation, but complements it.

\subsection{Interpretation and Construction}

Corbin's complementary conception of interpretation and construction can be restated as follows: interpretation identifies the meaning of some words or actions, construction their legal effect. Rules of interpretation are used to discern the meaning of what parties say and do; rules of construction determine the resulting legal state of affairs.

One might think of rules of interpretation and rules of construction as two types of functions. A rule of interpretation takes as its input some domain of interpretive evidence. That evidence necessarily includes the act or omission whose meaning is at issue, which I will call the "interpretive object," as well as the interpreter's background linguistic and practical knowledge. Depending on the rule being applied, the interpretive input in a contract case might also include dictionary definitions and rules of syntax, testimony or other evidence of local linguistic practices, what was said during negotiations, any course of performance under the agreement at issue, any prior similar transactions between the parties, testimony as to how participants in the transaction meant or understood the interpretive object, evidence of the parties' reasons or motives for entering into the exchange, and so forth. A rule of interpretation maps that input onto a meaning, which interpretation ascribes to the interpretive object. 
The output of legal interpretation-the meaning ascribed to the interpretive object-serves as an input for construction. Construction might take other input as well. A rule of contract construction might, for example, condition legal effects not only on what the speaker says-the meaning of her words and actions-but also on who she is, on the form in which she expresses herself, or on her use of conventional words or acts. And as will be discussed below, sometimes rule of construction requires no interpretation, as when parties employ a formality. A rule of construction maps those inputs onto a legal state of affairs. That is, it identifies their legal effect.

I will use "exposition" to refer to the entire process of determining the legal effect of a person or persons' words or actions. Exposition commonly involves both interpretation and construction. In the process of exposition, interpretation comes first, construction second. The reason is not, as Lieber and Williston suggest, that construction steps in only when interpretation runs out. It is that one generally must decide what words or actions mean before one can know their legal effects. As Corbin says, "A 'meaning' must be given to the words before determining their legal operation." ${ }^{45}$ Or as I have put the point, the output of legal interpretation serves as the input for construction. That said, later parts of this Article identify other senses in which construction is sometimes or always prior to interpretation.

Although the interpretation-construction distinction has been around for over a century and a half, it is often ignored. Many contract scholars use "interpretation" to refer to the activity of construction. Ian Ayres: "Algebraically, one could think of interpretation as a function, $f()$, that relates actions of contractual parties, $a$, and the surrounding circumstances or contexts, $c$, to particular legal effects, e." ${ }^{46}$ Richard Posner: "Contract interpretation is the undertaking . . . to figure out what the terms of a contract are, or should be understood to be." ${ }^{\prime 47}$ Alan Schwartz and Robert Scott: "[A] theory of interpretation ... 'maps' from the semantic content of the parties' writing to the writing's legal implications." 48 Contrariwise, and especially among British jurists and scholars, it is not uncommon to use "construction" to refer to the search for objective meaning, which is a form of interpretation as I am using the term. ${ }^{49}$

${ }^{45}$ Corbin (1st ed.) § 534, 8.

${ }^{46}$ Ayres, supra note 4 at 2046.

${ }^{47}$ Richard A. Posner, The Law and Economics of Contract Interpretation, 83 Tex. L. Rev. 1581, 1582 (2005)

${ }^{48}$ Alan Schwartz \& Robert E. Scott, Contract Theory and the Limits of Contract Law, 113 Yale L.J. 541, 547 (2003).

${ }^{49}$ For example, in his treatise, The Construction of Commercial Contracts, J.W. Carter defines "construction" as "the process by which the intention of the parties to a contract is determined and given effect to," and argues that 
These façons de parler are fine as far as they go. The technical definitions of "interpretation" and "construction" depart from those words' everyday meanings, and there is nothing wrong with using common words in accordance with common usage. But there is a difference between the activities of interpretation and construction. Corbin again: "there is no identity nor much similarity between the process of giving a meaning to words, and the determination by the court of their legal operation." ${ }^{\prime 50}$ Attention to the difference, and to the different rules that govern each activity, is essential to a clear understanding of how law translates words and actions into legal effects. The advantage of adhering to the terms' technical meanings is that it forces one to keep in view the difference between the two activities, and to be clear about what one is talking about when.

\section{Rules of Contract Construction}

Having distinguished the activities of interpretation and construction, it is now possible to take a closer look at the rules that govern each. This Part provides an account of the rules of contract construction; Part Three discusses varieties of contract interpretation.

The rules of contract construction divide into three broad categories: mandatory rules, default rules and altering rules. A mandatory rule specifies a legal state of affairs that applies no matter what legal actors say and do. Thus when the Second Restatement observes that "[e]very contract imposes upon each party a duty of good faith and fair dealing in its performance and its enforcement," it states that the parties who have entered into a contract have a duty of good faith no matter what. ${ }^{51}$ The duty cannot be disclaimed. Other examples include the minimum wage and civil rights laws, the penalty rule for liquidated damages, and the nonenforcement of contracts contrary to public policy. A default rule specifies the legal state of affairs absent evidence the right person's or persons' contrary intent. Familiar examples in contract law include the rule that an offer on which the offeree has not relied is revocable; ${ }^{52}$ the implied

"since even a decision on the linguistic meaning of words may determine the legal rights of the parties, there seems little point in seeking to distinguish between a process called 'interpretation' and one which is termed 'construction." J.W. Carter, The Construction of Commercial Contracts 4 \& 6 (2013).

${ }^{50} 3$ Corbin (1st ed.) § 534, 11.

${ }^{51}$ Restatement (Second) of Contracts $\S 205$ (1981). This is not to say that the parties cannot alter the specific requirements of that obligation through their words and actions. The point is only that they cannot escape the duty altogether.

${ }^{52}$ See Restatement (Second) of Contracts $\S 42 \mathrm{cmt}$. a (1981). 
warranty of merchantability that attaches to a merchant's sale of goods; ${ }^{53}$ and most rules governing the calculation of damages for breach. ${ }^{54}$ An altering rule specifies whose saying of what suffices to effect one or another change from the default legal state of affairs. ${ }^{55}$ Thus a merchant selling goods can make her offer irrevocable for up to three months by expressing her intent to do so in a signed writing, ${ }^{56}$ a seller can disclaim the implied warranty of merchantability by using words like "as is" or "with all faults", ${ }^{57}$ and parties can generally agree to liquidate or limit damages for breach by expressing their shared intent to do so. ${ }^{58}$

This Part focuses on default and altering rules, which together translate parties' words and actions into contractual obligations.

\subsection{Default Rules}

Contract scholars often speak of default rules as "rules of interpretation," and commonly use terms like "default interpretations" or "interpretive defaults." ${ }^{59}$ One reason for this way of speaking is inattention to the interpretation-construction distinction. The inattention is fine so long as everyone is clear that "interpretation" is being used to include construction. If one attends to the difference between the two activities, it is clear that default rules are rules of construction. A default rule determines the legal state of affairs absent the parties' expression to the contrary. As Corbin observes, "[w] hen a court is filling gaps in the terms of an agreement, with respect to matters that the parties did not have in contemplation and as to which they had no intention to be expressed, the judicial process .... . may be called 'construction'; it should not be called 'interpretation.'" 60

Another reason why contract scholars might associate defaults with rules of interpretation is that defaults rules are often designed to get at what

${ }^{53}$ U.C.C. § 2-314(1).

${ }^{54}$ See Restatement (Second) of Contracts §§ 346-52 (1981).

${ }^{55}$ I take this term from lan Ayres's important work, Regulating Opt-Out: An Economic Theory of Altering Rules, 121 Yale L.J. 2032 (2012). See also Brett McDonnell, Sticky Defaults and Altering Rules in Corporate Law, 60 SMU L. Rev. 383 (2007). In earlier work, I have analyzed altering rules under the heading of "opt-out" rules. Gregory Klass, Intent to Contract, 95 Va. L. Rev. 1437 (2009).

${ }^{56}$ U.C.C. $\$ 2-205$.

${ }^{57}$ U.C.C. $\$ 2-316(3)(\mathrm{a})$.

${ }^{58}$ Restatement (Second) of Contracts $\S 356$ (1981).

${ }^{59}$ A search of Westlaw's JLR database finds 85 articles using "default interpretation," 88 using "interpretive default," and 52 using "default rule of interpretation." Search run on January 2, 2018.

${ }^{60} 3$ Corbin (1st ed.) $\S 534$ at 9. 
parties probably intended, or would have intended had they thought about the matter, and these can look like interpretive questions. Thus Richard Posner writes: "Gap filling and disambiguation are both . . . 'interpretive' in the sense that they are efforts to determine how the parties would have resolved the issue that has arisen had they foreseen it when they negotiated their contract." ${ }^{61}$

I do not want to claim a monopoly on the word "interpretation." But neither setting a majoritarian default nor seeking what particular parties would have agreed to requires interpretation in the sense in which this Article uses the term. Predicting parties' probable preferences or intentions is not the same as interpreting what individual parties said or did in a particular transaction. ${ }^{62}$ Moreover, not all default rules are or should be majoritarian ones or correspond to what the parties would have agreed to. ${ }^{63}$ Lawmakers might set the default to accord with public policy or other social interests as a way to guide parties to socially desirable outcomes. Or they might adopt a penalty default that is designed not to get at the terms most parties want or would have chosen, but to give one or both parties a new reason to share information by opting out of the default.

The above paragraphs barely scratch the surface of the extensive literature on default rules in contract law. This Article's primary contribution to that literature is simply to clarify how one should understand of default rules. Default rules are not rules of interpretation, but rules of construction. Once one recognizes this fact, it is not surprising that they might be designed with a view to factors other than parties' probable intentions or hypothetical agreement. The social interests in the enforcement contractual agreements extend beyond party choice.

\subsection{Altering Rules}

Every default comes with an altering rule. To describe a legal state of affairs as a default is to say that some person or persons might change it by saying the right thing in the right way. Who must say what how is determined by an altering rule. As Ian Ayres writes, "[a]n altering rule in essence says that if contractors say or do this, they will achieve a particular

${ }^{61}$ Posner, supra note 47 at 1586.

${ }^{62}$ For a variation on this point, see Seana Valentine Shiffrin, Must I Mean What You Think I Should Have Said?, 98 Va. L. Rev. 159, 163 (2012); Gregory Klass, To Perform or Pay Damages, 98 Va. L. Rev. 143, 145-47 (2012).

${ }^{63}$ Ian Ayres \& Robert Gertner, Filling Gaps in Incomplete Contracts: An Economic Theory of Default Rules, 99 Yale L.J. 87 (1989). 
contractual result." ${ }^{\prime 64}$ Because altering rules describe the legal effects of what parties say and do, they too are rules of construction.

All altering rules share a tripartite structure specifying actor, act and effect. An altering rule provides that if (1) the right actor or actors (2) performs a specified act, then (3) a certain nondefault legal state of affairs will pertain. Article Two's rule for firm offers not supported by consideration provides a useful example. The default rule for offers is that they are revocable. Section 2-205 provides an associated altering rule:

An offer by a merchant to buy or sell goods in a signed writing which by its terms gives assurance that it will be held open is not revocable, for lack of consideration, during the time stated or if no time is stated for a reasonable time, but in no event may such period of irrevocability exceed three months.

The rule establishes (1) whose acts are relevant: those of a merchant buyer or seller of goods; (2) what acts are sufficient to displace the default: a signed written assurance that the offer will be held open; and (3) the term that substitutes for the default: irrevocability for the time stated or, if no time is stated, for a reasonable time, but in no case for more than three months. This Article focuses on the second element of altering rules: the identification of acts that suffice to displace the default. I call these "altering acts."

Altering acts can have multiple salient features. Consider again the section 2-205 rule for firm offers. In order to be irrevocable under the rule, a merchant's offer must satisfy three requirements. It must (a) "by its terms give[] assurance that it will be held open," (b) be in writing, and (c) be signed. Determining whether the first requirement is met-whether the right sort of assurance was given-requires interpretation, even if only to ascertain the literal meaning of the merchant's words. Determining whether the second and third requirements are satisfied-whether the assurance was in writing and whether it was signed-does not require interpretation. The first requirement is that the offer perform an act with the right meaning, the second and third that the act be of the right form.

I will call rules that condition legal outcomes on the meaning of what the parties say and do "interpretive components" of altering rules, and rules that condition legal outcomes on facts that can be ascertained without

${ }^{64}$ Ayres, supra note 4 at 2036. I do not think that Ayres gets things quite right when he writes that altering rules are "the necessary and sufficient conditions for displacing a default legal treatment with some particular other legal treatment." Id. at 2036. It is more helpful to think of altering rules as specifying acts sufficient to displace a default, but not necessary to do so. Contract law often provides several separate paths to effecting a legal change. 
interpretation "formal components." An interpretive component requires interpretation of the parties' words and actions to determine whether they have effected a legal change. A formal component requires examination of formal qualities of the parties' words and actions.

Any given altering rule might have only interpretive components, only formal components, or a mix of the two. I will say that an altering rule that includes only formal components is "formalistic," and the altering acts such a rule specifies "formalities." Consider section 2-319 of the Code, which provides that, "when the term is F.O.B. the place of shipment, the seller must at that place ship the goods in the manner provided in this Article ... and bear the expense and risk of putting them into the possession of the carrier." According to this rule, the letters "F.O.B." plus the name of a place suffice to effect the legal change. No further inquiry into what the parties or their words meant is required. The rule is a formalistic one, establishing "F.O.B." as a legal formality. The section 2-316 rule for "as is" and "with all faults" is similarly formalistic. It provides that, ceteris paribus, the mere use of those words is enough to exclude all implied warranties. So too, famously, the common law and statutory rules governing the legal effect of the seal. ${ }^{65}$

I will say that altering rules that are not formalistic are "interpretive." Interpretive altering rules always contain an interpretive component. The application of an interpretive altering rule requires interpretation of the parties' words and actions. Interpretation enters the process of legal exposition by way of interpretive altering rules.

An interpretive altering rule might or might not include formal components. I will call altering rules that do not include formal components "pure interpretive altering rules." The Second Restatement defines an offer, for example, as any "manifestation of willingness to enter into a bargain." 66 The rule requires interpretation of a party's words and actions to determine whether there has been an offer. But it does not condition the legal effect of those words or actions on their formal qualities, such appearing in a writing or with a signature. Similarly, UCC section

${ }^{65}$ Altering rules can specify legal effects that are either defeasible or nondefeasible, depending on whether the resultant legal state of affairs is default or mandatory. Most modern formalistic altering rules establish defeasible effects. The Second Restatement, for example, provides that "[t]he adoption of a seal may be shown or negated by any relevant evidence as to the intention manifested by the promisor." Restatement (Second) Contracts $\S 98 \mathrm{cmt}$. a (1981). See also 1 Williston on Contracts $\S 2: 2$ n.11 (4th ed. 2016) (citing cases); Eric Mills Holmes, Stature \& Status of a Promise Under Seal as a Legal Formality, 29 Willamette L. Rev. 617, 636-37 (1993) (discussing the modern requirement of a party's intent to deliver the sealed instrument).

${ }^{66}$ Restatement (Second) of Contracts $\S 24$ (1981). 
2-204's formation rule: "A contract for sale of goods may be made in any manner sufficient to show agreement, including conduct by both parties which recognizes the existence of such a contract." ${ }^{67}$ Determining whether the parties have agreed to a sale of goods requires interpreting their words and conduct. The rule is an interpretive one. Because section 2-204 does not impose any formal requirements, it too is a pure interpretive altering rule. $^{68}$

I will call interpretive altering rules that that have one or more formal components "mixed interpretive rules." The section 2-205 rule for firm offers is a mixed interpretive rule. It requires both that a merchant seller say words with the right meaning — that the offer "by its terms gives assurances that it will be held open" — and that those words be in the right form- "in a signed writing." A merchant's offer must satisfy both the interpretive and the formal components to be a firm offer pursuant to the rule.

The distinction between formal and informal components therefore produces a typology of altering rules that can be represented in a two-bytwo table.

Types of altering rules

Interpretive Component

\begin{tabular}{lc|c|c|}
\multicolumn{1}{c|}{} & \multicolumn{2}{c|}{ Yes } \\
\cline { 3 - 4 } \multicolumn{1}{c|}{ Yes } & $\begin{array}{c}\text { mixed } \\
\text { interpretive rules } \\
\text { (UCC rule for firm } \\
\text { offers) }\end{array}$ & $\begin{array}{c}\text { Normalistic rules } \\
\text { ("as is," "F.O.B.") }\end{array}$ \\
\cline { 3 - 3 } & Nomponent & $\begin{array}{l}\text { pure } \\
\text { interpretive rules } \\
\text { (generic rules for } \\
\text { agreement) }\end{array}$ \\
\hline
\end{tabular}

Part Three discusses interpretive altering rules. Formalistic altering rules figure into the discussion of Part Four.

Lastly, it is worth nothing that altering rules themselves can be mandatory or default rules. Contract law grants parties broad powers not only over their first-order legal obligations to one another-roughly, the

${ }^{67}$ U.C.C. $\S 2-204$.

${ }^{68}$ Other sections of the code add formal requirements for some contract types, most obviously the Code's Statute of Frauds. U.C.C. § 2-201. 
obligations whose nonperformance constitutes a breach ${ }^{69}$ —but sometimes also over the framework rules that determine when those obligations come into existence and what their content is.

The mailbox rule provides a simple example. The rule establishes precisely when an acceptance effects a legal change, and is therefore a component of the effects-prong of formation altering rules. A mailed acceptance is effective "as soon as it is put out of the offeree's possession, without regard to whether it ever reaches the offeror." ${ }^{\prime 70}$ That rule, however, does not apply if "the offer provides otherwise." ${ }^{\prime 71}$ The mailbox rule itself is a default rule. An offeror has the power to stipulate, for example, that an acceptance shall be effective only upon receipt.

The parol evidence rule provides another, somewhat more complex, example. The contemporary default rule is that writings are given no special weight in determining parties' contractual obligations. ${ }^{72}$ If, however, parties agree that a writing shall serve as a final expression of some or all of the contract between them —-that the writing shall be "integrated" — parol evidence of contrary or additional terms is generally excluded. ${ }^{73}$ Integration alters the default legal effects of the writing and of extrinsic evidence. U.S. courts generally recognize two ways parties can effectively express or evince their shared intent that a writing be integrated. They can include in the writing an integration clause, which expressly states that it is the final statement of some or all terms. Or, absent an integration clause, a writing will be judged integrated if "in view of its completeness and specificity reasonably appears to be a complete agreement, it is taken to be an integrated agreement." 74 These are altering rules. Each specifies how parties can effectively express their intent that the writing serve as a final statement of terms.

Although many rules of construction are defaults, there are also mandatory limits on the parties' ability pick and choose those rules. A clause that requires modifications to be in writing might be ineffective

${ }^{69}$ In addition to first-order duties, a contract might provide for first-order permissions, powers and other legal relations. Here and in much of the rest of this essay, for the sake of simplicity I ignore these other types of contract terms.

${ }^{70}$ Restatement (Second) Contracts $\S 63$ (1981).

${ }^{71} / d$.

${ }^{72}$ This was not always the case. Under the old best evidence rule, a writing automatically excluded all oral evidence of contrary terms. The best evidence rule established an evidentiary hierarchy: written evidence, which was commonly under seal, could not be contradicted by oral evidence. See, e.g., Salmond, The Superiority of Written Evidence, 6 L. Q. Rev. 75 (1890).

${ }^{73}$ Restatement (Second) of Contracts § 213 (1981).

${ }^{74}$ Restatement (Second) of Contracts § 209(3) (1981). 
under common law, though effective under the Uniform Commercial Code. ${ }^{75}$ Courts do not enforce provisions that purport to alter the rules governing waivers. ${ }^{76}$ And integration will not prevent a party from later introducing parol evidence of "illegality, fraud, duress, mistake, lack of consideration, or other invalidating cause. ${ }^{177}$

The analysis so far can be summarized as follows. Legal exposition involves two separate activities: interpretation, which identifies the meaning of the parties' words and actions, and construction, which identifies their legal effect. Rules of construction include mandatory, default and altering rules. A mandatory rule says what the legal state of affairs is no matter what the parties say or do. A default rule says what the legal state of affairs is absent the parties' contrary expression. An altering rule identifies contrary expressions sufficient to effect a change from the default. Altering rules can have interpretive and formal components. Interpretive components condition legal change on the performance of acts with the right meaning. Formal components condition legal change on the performance of acts of the right form. Formalistic altering rules have only formal components. Pure interpretive rules have only interpretive components. Mixed interpretive rules have both formal and interpretive components.

Conceptual distinctions and taxonomies are of value when they shed new light on old questions. The argument for the above categories can therefore be found in the remainder of this Article. That said, it is already possible to identify an example of their utility. Eric Posner has suggested that "[a]n interesting aspect of the Statute of Frauds and other contract formalities is that they do not fit easily into the default-immutable rule dichotomy frequently used by contract theorists. ${ }^{\prime 78}$ The reason is that the default-immutable rule, or default-mandatory rule, dichotomy is incomplete. Statutes of Frauds and other formal requirements belong to a third category: altering rules. A writing requirement like a Statute of Frauds is not itself an altering rule, but is sometimes a component of other altering

${ }^{75}$ See Samuel Williston, 29 Williston on Contracts $\S 73: 22$ (4th ed.) (nooral-modification clauses ineffective); U.C.C. 2-209(2) (no-oralmodification clauses effective).

${ }^{76}$ See 13 Williston on Contracts $\S 39: 36$ (4th ed.) (" $[\mathrm{A}]$ provision that a term or condition of any sort cannot be eliminated by a waiver, or by an estoppel, is ineffective, and a party has the same power to waive the condition, or to be estopped from asserting it, as though the provision did not exist.").

${ }^{77}$ Restatement (Second) Contracts $\S 214(d)$ (1981).

${ }^{78}$ Eric A. Posner, Norms, Formalities, and the Statute of Frauds: A

Comment, 144 U. Pa. L. Rev. 1971, 1981 (1996). 
rules. In the transactions to which it applies, a Statute of Frauds adds a formal component: the parties' agreement must be evidenced by a signed writing. ${ }^{79}$ Altering rules and their components, like any other framework contract rules, can themselves be mandatory or default. As it happens, Statutes of Frauds are mandatory components of the altering rules into which they figure. Parties cannot contract out of their writing requirements. Although a complete understanding of such formal requirements demands a richer conceptual toolkit, a Statute of Frauds therefore also fits "into the default-immutable rule dichotomy."

\section{The Varieties of Contract Interpretation}

Part One emphasized differences among how Lieber, Williston and Corbin conceive interpretation and construction and the relationship between the two activities. But there is a similarity among their understandings of interpretation. Each has a relatively narrow conception of meaning. For Lieber, "[t]rue sense is . . the meaning which the person or persons, who made use of the words, intended to convey to others, whether he used them correctly, skillfully, logically or not." ${ }^{80}$ Williston follows Lieber's intentionalist account: "Interpretation is the art of finding out the true sense of any form of words: that is, the sense which their author intended to convey, and of enabling others to derive from them the very same idea which the author intended to convey. ${ }^{81}$ Corbin adopts a listenercentered account of meaning, but one that is similarly one-dimensional. "By 'interpretation of language' we determine what ideas that language induces in other persons." ${ }^{82}$

These simple accounts of meaning, and by extension interpretation, oversimplify. This Part argues that contract law's interpretive altering rules recognize and give legal effect to several different types of meaning. ${ }^{83}$ These

${ }^{79}$ This is roughly the basic requirement of Article Two's writing requirement. U.C.C. § 2-201(1). The rule in section 2-201 of the Code contains exceptions and qualifications that are not captured in the above. And other Statutes of Frauds require additional things of the writing. The Second Restatement, for example, suggests that the contents of the writing must (1) reasonably identify the subject matter of the contract; (2) indicate that a contract has been made; and (3) state the essential terms of the unperformed promise. Restatement (Second) Contracts § 131 (1981).

${ }^{80}$ Lieber, supra note 7 at 23. See also id. at 19 ("[I]t is necessary for him, for whose benefit [a sign] is intended, to find out, what those persons who use the sign, intend to convey to the mind of the beholder or hearer.").

${ }^{81}$ Williston (1st ed.) § 602, at 1159-60 (quoting Lieber, supra note 7 at 23).

${ }^{82}$ Corbin (1st ed.) $\S 534$, at 7.

${ }^{83}$ Lieber expressly rejects the idea that there are multiple types of meaning relevant to the law, contrasting legal to Biblical interpretation. 
include plain meaning, context dependent use meaning, subjective and objective meaning, an agreement's or term's purpose, and the parties' intentions and beliefs. Each can, under the right circumstances, figure into determining the existence or content of a contract. Each is identified by interpretation of the parties' words and actions. And the legal relevance of each is determined by a rule of construction.

Two scholars have recently suggested that public laws too have multiple meanings. Cass Sunstein argues that "there is nothing that interpretation "just is," and that "no approach to constitutional interpretation is mandatory. ${ }^{\prime 84}$ And Richard Fallon identifies a "diversity of senses of meaning that constitute ... potential 'referents' for claims of legal meaning. ${ }^{\prime 85}$ Sunstein suggests an outcome-based approach the choice among interpretive methods in constitutional law. "Among the reasonable alternatives, any particular approach to the Constitution must be defended on the ground that it makes the relevant constitutional order better rather than worse." ${ }^{86}$ To date Sunstein he has not made an outcome-based case for one or another form of constitutional interpretation. Fallon argues that it is a mistake to equate statutory or constitutional meaning with any one type of meaning. Rather than selecting a single mode of interpretation on the basis of overall outcomes, Fallon recommends "a relatively case-by-case approach to selecting" the appropriate sort of meaning. ${ }^{87}$

Neither Sunstein's nor Fallon's theory describes the choice of meaning in the law of contracts. In contract exposition, different types of meaning are relevant in different circumstance and to different legal questions. And generally accepted rules of construction govern which type of meaning is legally relevant when. Contract law thereby illustrates how legal exposition can incorporate multiple types of meaning in a rule-

Owing to the peculiar character which the Bible possesses, as a book of history and revelation, and the relation between the old and new testaments, we find that some divines ascribe various meanings to the same passages or rites, and that different theologians take the same passage in senses of an essentially different character. We hear thus of typical, allegorical, parabolical, anagogical, moral and accommodatory senses, and of corresponding modes of interpretation. ... In politics and law we have to deal with plain words and human use of them only.

Lieber, supra note 7 at 75-76.

${ }^{84}$ Cass Sunstein, There Is Nothing that Interpretation Just Is, 30 Const. Comment. 193, 193 (2015).

${ }^{85}$ Richard H. Fallon, Jr., The Meaning of Legal "Meaning" and Its Implications for Theories of Legal Interpretation, 82 U. Chi. L. Rev. 1235, 1239 (2015).

${ }^{86}$ Sunstein, supra note 84 at 212.

${ }^{87}$ Fallon, surpra note 85 at 1303. 
governed way. And it exemplifies how what counts as the right approach to legal interpretation depends on the relevant rule of construction, as the complementary conception suggests it must.

This Part focuses on the interpretation of contractual agreements. But it is worth remembering that agreements are not the only types of altering acts that contract law recognizes. Offers, rejections, counter offers, retractions, preliminary agreements, modifications, waivers, repudiations, demands for adequate assurance, cancellations, elections of remedies and other meaningful acts before and after formation can alter the parties' contractual rights, obligations, powers, privileges and so forth. All of commonly require interpretation to determine their legal effect. This Part makes only a start at describing the varieties of interpretation in contract law.

\subsection{Plain Meaning and Use Meaning}

Perhaps the most contested question about contract interpretation concerns the choice between plain meaning and use meaning. In contract law, "plain meaning" generally refers to the meaning an experienced interpreter can glean from a writing using nothing but a dictionary, her knowledge of the English language, and her generic understanding of the social world. Because plain meaning interpretation uses so few inputs, a writing's plain meaning often is its literal meaning. But not always. A written agreement read as a whole, for example, might evince a general purpose which suggests that a provision in it should not be read literally. As Williston explained in the first edition of his treatise:

in giving effect to the general meaning of a writing particular words are sometimes wholly disregarded, or supplied. Thus "or" may be given the meaning of "and," or vice versa, if the remainder of the agreement shows that a reasonable person in the position of the parties would so understand it. ${ }^{88}$

The plain meaning of words is their meaning stripped of context, but not entirely of apparent intention. ${ }^{89}$

I will use "use meaning" to refer to how a reasonable person would understand the parties' words or actions in light of the relevant circumstances of their use. An agreement's plain and use meanings sometimes diverge. Parties sometimes objectively use and understand words to mean something other than their plain meanings. To take a

${ }^{88} 2$ Williston (1st ed.) $§ 619,1199$.

${ }^{89}$ In other words, plain meaning is not necessarily semantic meaning. I discuss the distinction between semantic and pragmatic meaning in Part Four. 
famous example, consider a clause in a contract for the repair of a steam turbine that indemnifies the owner "against all loss, damage, expense and liability resulting from ... injury to property." Read literally and without context, the clause covers all losses, including those of the owner. But it is easy to imagine that the parties' reasons for adding the clause, their past dealings, or a course of performance could cause them to reasonably understand the clause to cover only third-party losses. In such a case, the words' plain meaning would diverge from their use meaning.

Contract law recognizes that even in an integrated writing-one that the parties intend to be a final statement of some or all terms of their agreement-plain meaning can diverge from use meaning. As just about every first-year US law student learns, US jurisdictions take different approaches to the possibility of such divergences. In Pacific Gas \& Electric v. G.W. Thomas Drayage \& Rigging, the California Supreme Court held,

The test of admissibility of extrinsic evidence to explain the meaning of a written instrument is not whether it appears to the court to be plain and unambiguous on its face, but whether the offered evidence is relevant to prove a meaning to which the language of the instrument is reasonably susceptible. ${ }^{90}$

This California rule eschews exclusive reliance on plain meaning and instructs courts to look in the first instance to an integrated writing's use meaning - to how the parties reasonably understood the words in the circumstances of the writing's production. At issue in Pacific Gas was the legal effect of the above indemnification clause. The court concluded that the defendant should have been allowed to introduce extrinsic evidence that the parties understood the clause to cover only third-party losses.

New York courts apply a very different rule. In W.W.W. Assoc. $v$ Giancontieri, for example, the New York Court of Appeals held that "when parties set down their agreement in a clear, complete document, ... [e]vidence outside the four corners of the document as to what was really intended but unstated or misstated is generally inadmissible to add to or vary the writing." ${ }^{\prime 11}$ Under Giancontieri, when the plain meaning of an integrated writing is unambiguous, that meaning governs. In New York, the Pacific Gas indemnification clause would cover both third-party and owner losses.

There is a lively debate among contracts scholars as to which rule is better. Interesting though the question is, I am not going to weigh in on it here. Instead, I want to make four points about the choice between plain and use meaning.

${ }^{90}$ Pac. Gas \& Elec. Co. v. G. W. Thomas Drayage \& Rigging Co., 442 P.2d 641, 644 (Cal. 1968).

${ }^{91}$ W.W.W. Associates, Inc. v. Giancontieri, 77 N.Y.2d 157, 162 (1990). 
First, both the Pacific Gas and the Giancontieri rules are rules of construction. More specifically, they are interpretive altering rules. Pacific Gas holds that the parties' legal obligations depend on the contextually determined use meaning of their words, even when the parties have reduced their agreement to an integrated writing that appears unambiguous on its face. The holding in Giancontieri is that when an integrated writing is on its face unambiguous, the parties' legal obligations depend on the writing's plain meaning only. Each rule establishes which type of meaning is legally salient.

Second, by determining which sort of meaning is legally salient, these rules thereby determine what sort of interpretation legal decision makers should engage in. In New York, a court should first aim to interpret an integrated agreement's plain meaning; in California it should begin with the writing's use meaning. I have observed that in the order of application, interpretation comes first, construction second. But because legal interpretation serves construction, the correct approach to legal interpretation depends on the applicable rule of construction. Rules of construction are conceptually prior to legal interpretation.

Third, the design choice is not simply between plain meaning and use meaning, but is about which type of meaning is relevant when. This is most obvious under the New York rule. Giancontieri states that if the plain meaning of an integrated writing is unambiguous, that meaning controls. When the writing's plain meaning is ambiguous, however, parties are free to introduce extrinsic evidence to show which meaning they intended and the reasonable understanding of the words in the context in which they were produced. ${ }^{92}$ In other words, when plain meaning runs out, legal interpreters should turn to use meaning. Nor is it obvious that New York courts would apply to the plain meaning rule to informal, non-integrated writings or to oral agreements. New York's plain meaning rule does not eschew use meaning altogether, but identifies a narrower band of cases in which use meaning is legally relevant than does the California rule.

Finally, both the California and the New York rules are probably default rules. Alan Schwartz and Robert Scott discuss examples of contract clauses that expressly instruct courts to construe the agreement according to its plain meaning. ${ }^{93}$ Alternatively, parties might include a clause instructing

92 See, e.g., Pouch Terminal, Inc. v. Hapag-Lloyd (Am.) Inc., 569 N.Y.S.2d 122, 123 (2d Dep't 1991) ("Where . . . the language of a contract is susceptible of varying but reasonable interpretations, the parties may submit extrinsic evidence as an aid in construction, and the resolution of the ambiguity is for the trier of fact").

${ }^{93}$ Alan Schwartz \& Robert E. Scott, Contract Interpretation Redux, 119 Yale L.J. 926, 955 (2010). 
courts to construe their agreement according to its use meaning. ${ }^{94}$ Although there is not much case law on the effectiveness of such contractual provisions, a court would be hard pressed to altogether ignore such instructions from sophisticated parties. And though the Second Restatement casts some doubt on the rule, integration can also make a difference to the choice between plain and use meaning. ${ }^{95}$

\subsection{Subjective and Objective Meaning}

The distinction between plain and use meaning is not the only divide among legally relevant meanings in contract cases. Rules of construction also govern the choice between subjective and objective meaning.

In contract law, "subjective meaning" refers to what a speaker actually intended her words and actions to communicate or to what a hearer actually understood them to mean, "objective meaning" to what a reasonable person would understand those words and actions to mean. Subjective meaning can be private; objective meaning is always public. In the casebook staple Embry v. Hargadine, McKittrick Dry Goods Co., for example, a Missouri appellate court considered the correct interpretation of the words "Go ahead, you're all right; get your men out and don't let that worry you," spoken by the company's president, McKittrick, to an employee, Embry, who was threatening to quit unless given a new contract. ${ }^{96}$ At trial the jury was instructed to find that there was a contract only "if you (the jury) find both parties thereby intended and did contract with each other for plaintiff's employment." ${ }^{\prime 97}$ The appellate court held this was an error. "[T]hough McKittrick may not have intended to employ Embry by what transpired between them ...., yet if what McKittrick said would have been taken by a reasonable man to be an employment, and Embry so understood it, it constituted a valid contract of employment." ${ }^{\prime 8}$ In

${ }^{94}$ See, e.g., Corthell v. Summit Thread Co., 167 A. 79, 80 (Me. 1933) (written agreement specifying that it "is to be interpreted in good faith on the basis of what is reasonable and intended and not technically").

${ }^{95}$ This was Williston's view. See 2 Williston (1st ed.) $\S 606,1165$. The Second Restatement is more equivocal on the point. Section 212(1) provides that "The interpretation of an integrated agreement is directed to the meaning of the terms of the writing or writings in the light of the circumstances." Yet section 212(2) suggests that when the plain meaning of a writing is unambiguous, that meaning is to be determined by the court rather than the finder of fact.

96105 S.W. 777, 777 (Mo. Ct. App. 1907).

${ }^{97}$ Id. at 778.

${ }^{98}$ Id. at 779. 
short, the existence of a contract depended on the objective meaning of the company president's statement, not on his subjective understanding of it.

Plain meaning is always objective, as the inputs of plain meaning interpretation do not include evidence of privately held understandings. Use meaning can be understood subjectively or objectively. Objective use meaning is the meaning a reasonable observer would attribute to the words or actions in the context of their use. Thus the court in Embry interpreted the objective use meaning of McKittrick's statement to be an agreement to renew the employment contract.

[W] hen [Embry] was complaining of the worry and mental distress he was under because of his uncertainty about the future, and his urgent need, either of an immediate contract with respondent, or a refusal by it to make one, leaving him free to seek employment elsewhere, McKittrick must have answered as he did for the purpose of assuring appellant that any apprehension was needless, as appellant's services would be retained by the respondent. The answer was unambiguous. ${ }^{99}$

An utterance's or writing's subjective use meaning is a party's actual understanding of it, which might or might not be how a reasonable observer would understand it in the circumstances of its production. If, as the jury might have found, McKittrick believed he was not agreeing to renew Embry's contract, McKittrick's subjective understanding of his words departed from their objective meaning in the circumstances of their utterance.

In the early twentieth century, scholars and jurists devoted considerable attention to the choice between subjective and objective forms of interpretation. ${ }^{100}$ With respect to the interpretation of contractual agreements, most courts today follow section 201 of the Second Restatement, which looks to a mix of subjective and objective meaning. Oversimplifying a bit, when the parties' subjective meanings converge, those subjective meanings govern; when the parties attach different subjective meanings to their words and actions, objective meaning governs. ${ }^{101}$

Section 201 is another interpretive altering rule. Like the rules in Pacific Gas and Giancontierri, it establishes when one or another type of meaning is legally effective. That rule of construction, in turn, tells

${ }^{99}$ Id. at 779-80.

${ }^{100}$ See generally Joseph M. Perillo, The Origins of the Objective Theory of Contract Formation and Interpretation, 69 Fordham L. Rev. 427 (2000).

${ }^{101}$ Restatement (Second) of Contracts § 201(1) (1981). For a detailed account, see Lawrence M. Solan, Contract as Agreement, 83 Notre Dame L. Rev. 353 (2007). 
adjudicators and others when to engage in what sort of interpretation when determining the legal effects of the parties' words and actions. If the pleadings or interpretation suggests that the parties' subjective understandings were in agreement, subjective meaning governs; if not, the objective meaning of their words and actions governs. Again, the correct approach to legal interpretation depends on a rule of construction. And that rule specifies that circumstances in which one or the other type of meaning controls.

\subsection{Purpose}

Rules of contract construction also sometimes condition legal outcomes on the purpose of an agreement or a term in it. The interpretation of purpose is somewhat different from the interpretation communicative meaning, be it plain meaning or use meaning. Purpose is more closely aligned with instrumental or practical reasoning. A party's purpose in entering into an agreement or agreeing to a term in it is the end she seeks to achieve. Although identifying an agreement's purpose requires understanding its communicative content, the rational reconstruction of reasons and motives plays a larger role. Interpreting an agreement's purpose is more like figuring out a tool's function by examining its parts. Although still a form of interpretation, the relevant evidence and inferences can differ from the interpretation of communicative meaning.

Section 202 of the Second Restatement, for example, provides a general rule of contract construction that emphasizes both use meaning and purpose: "Words and other conduct are interpreted in the light of all the circumstances, and if the principal purpose of the parties is ascertainable it is given great weight." ${ }^{102}$ But the interpretation of purpose does not always require evidence of surrounding context. As observed above, purpose also figures into plain meaning rules. Thus the New York Court of Appeals has recently reaffirmed that "[a] written contract will be read as a whole, and every part will be interpreted with reference to the whole; and if possible it will be so interpreted as to give effect to its general purpose." ${ }^{103}$

An older New York case, William C. Atwater \& Co. v. Panama R. Co., further illustrates the role purpose plays in plain meaning rules. At issue was an installment contract for the sale of coal and the legal effect of the following provision: "Any portion of the tonnage remaining unshipped at the date of expiration of this agreement shall be considered cancelled without notice."104 The sentence's literal meaning was that both parties would be released from liability for any coal unshipped by the end of the

102 Restatement (Second) of Contracts § 202(1).

${ }^{103}$ Westmoreland Coal Co. v. Entech, Inc., 100 N.Y.2d 352, 358 (2003)

(internal quotation marks omitted).

104159 N.E. 418 (N.Y. 1927). 
installment period. The buyer invoked the clause to attempt to avoid liability for coal that the seller chose not to ship due to the buyer's own refusal to accept earlier shipments. Reading the agreement as a whole, and in light of the seller's contractual option to reduce installments after a buyer breach, the Court of Appeals concluded that the clause's purpose was to cancel only installments unshipped as a result of the seller's exercise of that option. "Reason, equity, fairness-all such lights on the probably intention of the parties-show what the real agreement was." ${ }^{105}$ Interpretation of the term's purpose required an imaginative reconstruction of what the parties sought to accomplish with it. Atwater stands for the proposition that the apparent purpose of a term can be legally controlling at the expense of the words' literal meaning.

In addition to its generic relevance, purpose figures into several more specific rules of contract construction. A defense of supervening frustration exists, for example, "[w] here after a contract is made, a party's principal purpose is substantially frustrated without his fault." ${ }^{\prime 106}$ Article Two of the UCC provides that "[w] here circumstances cause an exclusive or limited remedy [such as liquidated damages] to fail of its essential purpose," the court may provide any other remedies available under the Code. ${ }^{107}$ And though a commitment to serve as a surety is generally subject to the Statute of Frauds' writing requirement, where the surety's main purpose is a pecuniary or business advantage, the agreement falls outside the scope of the Statute. ${ }^{108}$ Each is an example of an interpretive altering rule, for each specifies ways that the parties' or an agreement's purpose at the time of formation figures into determining the legal state of affairs, and the identification of purpose requires interpretation.

\subsection{Intention and Belief}

Yet other rules of contract law look to the parties' beliefs, intentions or other propositional attitudes. ${ }^{109}$

Implied-in-fact contracts provide a familiar example. Although contract law requires that each party agree to the transaction, it does not require that they express that agreement in so many words. "[W]here the parties do not explicitly manifest their intent to contract by words, their intent may be gathered by implication from their conduct, language, and

\footnotetext{
${ }^{105} / d$. at 419 .

106 Restatement (Second) of Contracts § 265.

107 U.C.C. 2-719(2).

${ }^{108}$ See Restatement (Second) of Contracts $\S 116$.

${ }^{109}$ A propositional attitude is a mental state that takes as its object a proposition, and can therefore be described using a verb plus a "that" clause, as in, "She believed that ..." or "They intended that ..."
} 
other circumstances attending the transaction. ${ }^{\prime 110}$ When one party alleges an implied-in-fact contract, the question is not what the parties said, but what in the circumstances they objectively believed or intended. The ultimate question is not the meaning of their words, but their apparent intentions.

A common fact pattern illustrates. Suppose an individual submits a potentially valuable idea to a business, the business uses the idea, and the individual then demands payment. If the parties did not expressly agree to compensation, the law looks to their reasonable expectations. "[A]n implied in fact contract may be found when the parties have an understanding that the recipient of a valuable idea has accepted and used the idea, knowing that compensation is expected for use of the idea, without paying the purveyor of the idea." ${ }^{111}$ This is an altering rule that determines when parties acquire contractual obligations. The dispositive question, however, is not the meaning of the parties said. It is, rather, what they objectively believed regarding the nature of the transaction.

Another group of examples can be found in formation rules that require that the parties intend legal liability. The black-letter law in most jurisdictions outside of the United States is that a contract exists only if, at the time of formation, the parties objectively intended that their agreement be legally binding. ${ }^{112}$ Although US law generally eschews this requirement, ${ }^{113}$ US courts condition the enforcement of some types of agreements on evidence of the parties' intent to be legally bound. Examples include preliminary agreements, agreements between family members and reporters' confidentiality promises. ${ }^{114}$ Under all these rules the legal question is not the communicative content of the parties' words or actions-parties need not say that they intend legal liability-but the parties' apparent intentions.

Consider the rules for preliminary agreements. During the course of negotiations sophisticated parties sometimes write down the terms they have agreed to, though other terms remain under negotiation. Courts have

${ }^{110}$ Featherston v. Steinhoff, 226 Mich. App. 584, 589 (1997).

${ }^{111}$ Wrench, LLC v. Taco Bell Corp., 51 F.Supp. 2d 840,__ (D. Mich. 1999) (emphasis added), reversed on other grounds, 256 F.3d 446 (6th Cir. 2001).

${ }^{112}$ See The Commission of European Contract Law, Principles of European Contract Law arts. 2:101, 2:102 and accompanying notes (Ole Lando \& Hugh Beale eds., 2000) (discussing European sources of law).

113 See Restatement (Second) of Contracts $\S 21$ (1981).

${ }^{114}$ See, e.g., Teachers Ins. and Annuity Ass'n of Am. v. Tribune Co., 670 F. Supp. 491 (S.D.N.Y. 1987) (preliminary agreements); Empro Mfg. Co. v. Ball-Co Mfg., Inc., 870 F.2d 423 (7th Cir. 1989) (preliminary agreements); Restatement (Second) of Contracts § $21 \mathrm{cmt}$. c (1981) (agreements between family members); Cohen v. Cowles Media Co., 457 N.W.2d 199 (Minn. 1990) (reporter's confidentiality promise). 
held that such preliminary agreements can create a legal duty to negotiate in good faith remaining open terms, but only if the parties intend the agreement to be legally binding. Thus in the seminal case of Teachers Insurance and Annuity Association v. Tribune, Judge Leval wrote:

There is a strong presumption against finding binding obligation in agreements which include open terms, call for future approvals and expressly anticipate future preparation and execution of contract documents. Nonetheless, if that is what the parties intended, courts should not frustrate their achieving that objective or disappoint legitimately bargained contract expectations. ${ }^{115}$

This too is an altering rule. It determines when parties shift from not having a duty to negotiate in good faith to having such a duty. Although the rule turns on the parties' legal intent, it does not require that they say that they intend to be legally bound. It asks instead whether the parties appear to intend a legally binding agreement. ${ }^{116}$ Thus in Teachers Insurance, Leval suggests a broad, all-things-considered inquiry into the parties objective intent, whose inputs include the language of agreement, the context of negotiations, the parties' motives, the number of open terms, the extent to which the agreement had been performed, and usage of trade. ${ }^{117}$

Both the rule for implied-in-fact contracts and the rule for preliminary agreements attach legal consequences to proof of one or both parties' beliefs or intentions. They are, therefore, interpretive altering rules. Some readers might find it a stretch to say that these mental states are part of the meaning of the parties' words and actions. But whether or not we call them "meaning," identifying the parties' beliefs, intentions or other legally salient propositional attitudes requires interpreting what they said and did. Attributing such mental states to others is a way of making sense of their behavior, linguistic and nonlinguistic. ${ }^{118}$ This type of interpretation is not the same as the interpretation of communicative content, or even purpose. But it is a type of interpretation nonetheless, and is required by wellestablished rules of construction. The parties' propositional attitudes are yet

115 Teachers Ins. and Annuity Ass'n of Am. v. Tribune Co., 670 F. Supp. 491, 499 (S.D.N.Y. 1987).

116 "In seeking to determine whether such a preliminary commitment should be considered binding, a court's task is, once again, to determine the intentions of the parties at the time of their entry into the understanding, as well as their manifestations to one another by which the understanding was reached." 670 F. Supp. at 499.

117670 F. Supp. at 499-503.

118 See, e.g., Daniel C. Dennett, The Intentional Stance (1989); Donald Davidson, Radical Interpretation, in Inquiries into Truth and Interpretation 125 (1984). 
another type of meaning that can, at times, be relevant to the determination of their contractual obligations.

The above discussion illustrates two features of contract exposition. First, to paraphrase Sunstein, there is no one thing that contract interpretation just is. There are multiple types of legally salient contract interpretation. Whereas in public law there might be a need to choose one interpretive approach, the rules of contract construction call for different types of interpretation depending on the particulars of the case and the legal question at issue. Thus, for example, determining the legal effect of an unambiguous integrated document requires a different type of interpretation than interpreting an informal oral agreement, both of which differ from the interpretation needed to determine whether there exists a contract implied in fact.

The potential relevance of multiple types of meaning suggests also the possibility of a hierarchy of meanings. Thus plain meaning rules commonly permit recourse to extrinsic evidence of use meaning in cases of ambiguity. When plain meaning interpretation runs out, use meaning interpretation steps in. In explaining his constitutional originalism, Randy Barnett has suggested that "[w]hen original meaning runs out, constitutional 'interpretation,' strictly speaking, is over, and some new noninterpretive activity must supplement the information revealed by interpretation. ${ }^{119}$ । doubt whether an originalist needs to agree with Barnett on this point. One might maintain that when a preferred form of original meaning-say original public meaning-does not decide a constitutional question, other types of constitutional meaning, and therefore other types of interpretation, should step in. But whether or not such a rule makes sense in constitutional law, multiple types of interpretation are the norm in the law of contracts. Contract interpretation need not end when one type of interpretation runs out.

Second, the above analysis demonstrates how legal interpretation stands in the service of construction. In order to determine what sort of interpretation is appropriate when, one needs a rule of construction. In the process of determining the legal effect of the parties' words or actions, interpretation comes first, construction second. But because legal interpretation is the handmaiden of construction, the rules of the former must satisfy the requirements of the latter. Rules of construction are conceptually prior to rules of legal interpretation.

The conceptual priority of construction and multiple types of meaning suggest that it is a mistake to attempt to argue for one or another

${ }^{119}$ Randy Barnett, The Gravitational Force of Originalism, 82 Fordham L. Rev. 411, 419 (2013) (emphasis added). 
theory of contract interpretation based a theory of meaning more generally. Consider Corbin's argument against plain meaning rules:

[I]t can hardly be insisted on too often or too vigorously that language at its best is always a defective and uncertain instrument, that words do not define themselves, that terms and sentences in a contract, a deed, or a will do not apply themselves to external objects and performances, that the meaning of such terms and sentences consists of the ideas that they induce in the mind of some individual person who uses or hears or reads them, and that seldom in a litigated case to the words of a contract convey one identical meaning to two contracting parties or to third persons. Therefore, it is invariably necessary, before a court can give any meaning to the words of a contract and can select one meaning rather than other possible ones as the basis for the determination of rights and other legal effects, that extrinsic evidence shall be heard to make the court aware of the "surrounding circumstances," including the persons, objects, and events to which the words can be applied and which caused the words to be used. ${ }^{120}$

Justice Traynor quotes the above passage in Pacific Gas. ${ }^{121}$ There are clear echoes it in comments to the Second Restatement and the UCC. ${ }^{122}$ And one finds similar claims in the writings of contemporary anti-formalists. ${ }^{123}$ The claim is, in essence, that there is no such thing as plain meaning. "' $[\mathrm{M}]$ eaning' cannot exist without a speaker or hearer," and "no word or phrase has one true and unalterable meaning." ${ }^{124}$ Meaning only happens

1203 Corbin (1st ed.) $\S 537$ at

121442 P.2d at 644-45.

${ }^{122}$ Restatement (Second) of Contracts $\S 212 \mathrm{cmt}$. b (1981) ("meaning can almost never be plain except in a context"); U.C.C. § 2-202 cmt. 1 ("This section definitively rejects ... [t] he premise that the language used has the meaning attributable to such language by rules of construction existing in the law rather than the meaning which arises out of the commercial context in which it was used.").

${ }^{123}$ See, e.g., Melvin Aron Eisenberg, The Emergence of Dynamic Contract Law, in 2 Theoretical Inq. L. 1, 27 (2001) ("The proper interpretation of all purposive expressions, including contractual expressions, is necessarily dynamic, because the meaning of a purposive expression is always determined in part by its context, and the context is prior to the expression."); E. Allen Farnsworth, "Meaning" in the Law of Contracts, 76 Yale L.J. 939 (1967) ("'The very concept of plain meaning finds scant support in semantics, where one of the cardinal teachings is the fallibility of language as a means of communication.").

1243 Corbin ( 1 st ed.) $\S 535$, n. $15 \&$ 
when words are used in a particular setting for a specific purpose. The idea that words could have a meaning apart form their use is a form of magical thinking from another era.

This argument is confused. First, it employs an overly simplistic a theory of meaning. Plain meaning might not always capture what parties are doing with their words. But it is a type of meaning nonetheless. One can interpret words without knowing the full context of their use. Second, there are many different types of meaning that can be relevant in contract cases_-plain and use, subjective and objective, an agreement's or term's purpose, and the parties' beliefs or intentions. Third, although the theory of language can tell us a great deal about how legal interpretation can work, it cannot tell us what form legal interpretation should take. A theory of language cannot tell us which type of interpretation best serves the policies and purposes behind the law of contract. For that we need a rule of construction.

\section{The Interplay Between Interpretation and Construction}

Part Three has demonstrated that the relationship between interpretation and construction is more complex than the supplemental conception recognizes. Although interpretation comes first in the process of exposition, the correct approach to interpretation depends on the relevant altering rule. Rules of construction are always conceptually prior to rules of legal interpretation. This Part identifies two other ways that construction sometimes precedes interpretation.

Describing them requires yet another distinction among types of meaning. Linguists and philosophers of language disagree about the best way to define "pragmatic" and "semantic" meaning. ${ }^{125}$ Some describe the distinction in terms the types of evidence that goes into interpretation, others in terms of the question that the interpreter asks of that evidence. For my purposes, the latter approach is preferable and the following formulations serve well. The pragmatic meaning of an utterance or text is the best interpretation of the speaker's communicative intentions. Thus Kent Bach describes the ascription of pragmatic meaning as follows:

The hearer ... seeks to identify the speaker's intention in making the utterance. In effect the hearer seeks to explain the fact that the

${ }^{125}$ The topic is rich enough to the subject of at least one doctoral dissertation. Börjesson, Kristin. The Semantics-Pragmatics Controversy (2014). Robyn Carston identifies five separate ways scholars have tried to draw the distinction. Robyn Carston, Linguistic Communication and the Semantics/Pragmatics Distinction, 165 Synthese 321, 322 (2008). See also Kent Bach, The Semantics/Pragmatic Distinction: What It Is and Why It Matters, Linguistische Berichte, Sonderheft 8, 33 (1997). 
speaker said what he said, in the way he said it. Because the intention is communicative, the hearer's task of identifying it is driven partly by the assumption that the speaker intends him to do this. The speaker succeeds in communicating if the hearer identifies his intention in this way, for communicative intentions are intentions whose "fulfillment consists in their recognition." 126

Semantic meaning, in distinction, is conventional meaning, which can be identified independently of the speaker's communicative intentions. ${ }^{127}$ The semantic meaning of a sentence lies first and foremost in the conventional or literal meanings of its words, together with the rules of syntax or grammar of the language they belong to. It might also include contextual elements whose contribution to meaning is governed by determinate rules, such as those governing indexicals such as "l," "you" and "those."128 Pragmatic meaning diverges from semantic meaning when speakers use their words in nonliteral ways. Familiar examples include irony, innuendo, metaphor, ellipsis, malapropism and the many forms of nonconventional conversational implicature. ${ }^{129}$

The distinction between pragmatic and semantic meaning does not map onto the various types of meaning and interpretation discussed in Part Three. For the most part, interpretive altering rules in the law of contract focus on the pragmatic meaning of what parties say and do-on the parties' apparent communicative intent. Thus the Embry court interpreted, "Go ahead, you're all right; get your men out and don't let that worry you," as an agreement to renew the contract, despite the words' literal meaning. The primacy of pragmatic meaning also explains why plain meaning is not always literal meaning. Where the literal meaning of an agreement is at odds with the agreement's apparent purpose when read as a whole, a court will treat the words as a slip of the pen and give legal effect to the pragmatic meaning of the parties' words at the expense of their semantic

${ }^{126}$ Bach, supra note 125 at 41 (quoting Kent Bach \& Robert M. Harnish, Linguistic Communication and Speech Acts 15 (1979)). The passage goes on to link this definition to the evidentiary conception of pragmatics. "Pragmatics is concerned with whatever information is relevant, over and above the linguistic properties of a sentence, to understanding its utterance." Id. Plain meaning rules demonstrate that the two conceptions of pragmatic meaning are not extensionally equivalent.

127 This negative definition can be found in Kent Bach, Thought and Reference 180-181 (1987).

128 See Bach supra note 125 at 37-40.

${ }^{129}$ See H.P. Grice, Logic and Conversation, in The Logic of Grammar 64 (Donald Davidson \& Gilbert Harman eds., 1975), reprinted in Paul Grice, Studies in the Ways of Words 22 (1989); Bach \& Harnish, supra note 126 at 
meaning. Thus on occasion, "'or' may be given the meaning of 'and,' or vice versa, if the remainder of the agreement shows that a reasonable person in the position of the parties would so understand it." ${ }^{\prime 30}$

Rules of construction can figure into the pragmatic meaning of what parties' say and do. This happens when parties choose their words in light of their legal consequences-in light of the altering rules that will determine their legal effect. Where this is the case, interpretation requires some understanding of the rules of construction the parties have in mind. I call this the "pragmatic priority" of construction. It is the topic of the second section of this Part.

If semantic meaning figures into contract law, it is primarily in formalistic altering rules. A formalistic altering rule does not require that parties utter words with the right meaning, but only that they use the right words. For example, the words "F.O.B." plus the name of a location suffices to determine the seller's responsibility for shipment and to allocate the risk of loss if goods are damages before arrival. ${ }^{131}$ Formalistic altering rules attach conventional legal effects to certain words or acts, thereby giving them new semantic meanings. The first section of this Part discusses how acts of judicial construction can generate new formalistic altering rules, and thereby new semantic meanings. I call this the "semantic priority" of construction.

\subsection{Acts of Construction and Semantic Priority}

When during bidding a bridge player says, "Double," she is not using the word in its everyday sense. She is, rather, making a move in the game, effecting a change to how play will go forward. The rules of bridge give the ordinary word "double" a specialized function within that game. They give the word a new conventional, or semantic, meaning.

Formalistic altering rules similarly generate new semantic meanings. Consider again the legal use of "as is." The Uniform Commercial Code provides that "unless the circumstances indicate otherwise, all implied warranties are excluded by expressions like 'as is' [or] 'with all faults. '"132 Although the rule is written as if the phrases were mere examples, in practice it establishes that these ordinary-language terms suffice to achieve a specific legal effect: excluding implied warranties. ${ }^{133}$ Sophisticated parties

${ }^{130} 2$ Williston (1st ed.) $\S 619,1199$.

131 U.C.C. $\S 2-319$.

132 U.C.C. $\$ 2-316(3)(a)$.

133 See, e.g., Meyer v. Alex Lyon \& Son Sales Managers \& Auctioneers, Inc., 889 N.Y.S.2d 166 (1 st Dept. 2009) (holding that "as is" clause disclaimed all implied warranties without further inquiry); Welwood v. Cypress Creek Estates, Inc., 205 S.W.3d 722 (Tex.App.-Dallas 2006) (same); Prudential Ins. Co. of America v. Jefferson Associates, Ltd., 896 S.W.2d 156 (Tex. 
who encounter "as is" in a contract know that it is not being used to convey its non-legal meaning (arguably a tautology), but is there solely to achieve a specific legal effect. The formalistic altering rule gives the word a new semantic meaning.

Legal formalities come from a variety of sources. A statute might create a formality by fiat. Or it might codify historical patterns of use and legal effect among the legal community. Especially interesting for my purposes, and highly salient to the law of contracts, is the fact that acts of judicial construction can give a string of words a standard legal effect, thereby creating a new formality.

For several centuries, the standardized language in a Lloyd's marine insurance policy used the following words to describe covered risks:

Touching the Adventures and Perils which we the Assurers are contented to bear and do take upon us in this Voyage, they are, of the Seas, Men-of-War, Fire, Enemies, Pirates, Rovers, Thieves, Jettisons, Letters of Mart and Counter-mart, Surprisals, Takings at Sea, Arrests, Restraints and Detainments of all Kings, Princes, and People, of what Nation, Condition or Quality soever, Barratry of the Master and Mariners, and of all other Perils, Losses and Misfortunes that have or shall come to the Hurt, Detriment, or Damage of the said Goods and Merchandises and Ship, \&c., or any Part thereof. ${ }^{134}$

In his 1914 treatise, Sir Douglas Owen observed that "[i]f such a contract were to be drawn up for the first time to-day, it would be put down as the work of a lunatic endowed with a private sense of humour." ${ }^{135}$ But the "Adventures and Perils" clause in fact had an established set of legal consequences:

It is an ancient and incoherent document, occasionally the subject of judicial remarks in the highest degree uncomplimentary. But nobody minds this or dreams of altering the ancient form, nor, one may imagine, is it ever likely to be altered. Insurance experts know-or very often know-exactly what it means, and with generations of legal interpretations hanging almost to every word, and almost certainly to every sentence, in it, it would be highly dangerous to tamper with it. ${ }^{136}$

1995) (same); Warner v. Design and Build Homes, Inc., 114 P.3d 664 (Wash.App. Div. 2 2005) (same).

${ }^{134}$ I am grateful to Jim Oldham for bringing this example to my attention. See James C. Oldham, Insurance Litigation Involving the Zong and other British Slave Ships, 1780-1807, 28 J. Legal Hist. 299, 300 (2007).

${ }^{135}$ Sir Douglas Owen, Ocean Trade and Shipping 158 (1914).

${ }^{136}$ Id. at 155 . 
Lloyd's "Adventures and Perils" clause was a legal formality. Years of judicial construction gave the clause a standard legal effect, thereby generating a formalistic altering rule. That rule, in turn, gave the clause a new conventional, or semantic, meaning.

I call this the "semantic priority" of construction. The semantic priority of construction is a type of etymological priority. Judicial construction of nontechnical words can give those words new conventional legal meanings going forward. Construction can transform ordinary words into legal formalities.

The semantic priority of construction is a contingent feature of the legal system we have. If judicial construction sometimes generates new formalities, it is only because judicial decisions are both backward and forward looking. When a text's legal effect of is at issue, the court's job is to construe the effects of the words that appear in it. As Lawrence Solum puts the point, the question concerns a particular tokening of those words. ${ }^{137}$ At the same time, principles of stare decisis mean that this backward-looking decision can have forward-looking legal effects. The decision can also determine the legal consequences of future uses of the type.

But principles of stare decisis alone do not explain the semantic priority of construction in contract cases. It is a familiar fact that the same words often acquire different shades of meaning in different circumstances. If the fundamental principle of contract exposition is to ascertain the parties' intentions, it is not obvious why the construction of words in one contractual agreement should ever govern the construction of that same words in a different one.

There is, however, an instrumental advantage to that result. Formalities provide sophisticated parties cheap and effective tools with which to achieve the legal effects they want. As Lon Fuller observed, "form offers a legal framework into which the party may fit his actions, or, to change the figure, it offers channels for the legally effective expression of intention." ${ }^{138}$ Interpretive inquiries into parties' intentions can be uncertain and their results difficult to predict. By rendering interpretation unnecessary, a formality gives sophisticated parties an instrument for realizing those intentions. Allowing the construction of a string of words in one agreement to govern the construction of the same words in other agreements is a way of generating new, potentially useful formalities.

And in fact, the Second Restatement authorizes this result. Section 212(2) provides that when a party adopts a writing knowing that it is the standard form for a transaction, the writing "is interpreted wherever

${ }^{137}$ Lawrence B. Solum, The Fixation Thesis: The Role of Historical Fact in Original Meaning, 1 Notre Dame L. Rev. 1, 35-41 (2015).

${ }^{138}$ Lon L. Fuller, Consideration and Form, 41 Colum. L. Rev. 799, 801 (1941). 
reasonable as treating alike all those similarly situated, without regard to [the parties'] knowledge or understanding of the standard terms of the writing." ${ }^{139}$ Although the Restatement uses the word "interpret," section $211(2)$ is a rule of construction. It tells courts to treat boilerplate as having the same legal effect across multiple transactions, even if those transactions involve different parties with different background and occur in different circumstances. The rule authorizes the creation of new formalities by way of the judicial construction of contractual agreements. The reason for the rule is the practical advantages of contract formalities.

The danger of legal formalities, of course, is that unsophisticated parties might not understand the legal effects of their words or actions. A buyer who does not know the legal meaning of "as is" might not understand what she is getting in a sale. The danger is especially salient when it comes to judicially generated boilerplate formalities.

Consumer insurance law provides an example. Many courts today apply the doctrine of reasonable expectations: "The objectively reasonable expectations of applicants and intended beneficiaries regarding the terms of insurance contracts will be honored even though painstaking study of the policy provisions would have negated those expectations." ${ }^{140}$ The doctrine of reasonable expectations is another rule of construction that authorizes courts to give a clause a legal effect that departs from its plain meaning, thereby creating a gap between the best interpretation of a contractual agreement and the parties' legal obligations.

The doctrine's become more interesting when later courts apply the same construction to other contracts, in accordance with the principle of section 211(2). At this point the clause at issue has become a formality. But because the formality originated in an application of the doctrine of reasonable expectations, its conventional legal meaning cannot be found in the contract language. As Michelle Boardman observes, the result is that "[b]oilerplate that has repeatedly been construed by courts will take on a set, common meaning [i.e., legal effect], but one that may not be easily understood by reading the language itself." ${ }^{141}$ Thus applications of a rule of

${ }^{139}$ Restatement (Second) of Contracts § 211(2) (1981).

${ }^{140}$ Robert E. Keeton, Insurance Law Rights at Variance with Policy Provisions, 83 Harv. L. Rev. 961, 967 (1970). Keeton's article was the first to articulate the principle, based on his collection of cases. For discussions of subsequent developments in the doctrine, see Kenneth S. Abraham, Judge-Made Law and Judge-Made Insurance: Honoring the Reasonable Expectations of the Insured, 67 Va. L. Rev. 1151 (1981); Roger C.

Henderson, The Doctrine of Reasonable Expectations in Insurance Law After Two Decades, 51 Ohio St. L.J. 823 (1990); Peter Nash Swisher, A Realistic Consensus Approach to the Insurance Law Doctrine of Reasonable Expectations, 35 Tort \& Ins. L.J. 729 (2000).

${ }^{141}$ Id. at 1111. 
construction that is intended to protect insureds - the doctrine of reasonable expectations_-can generate legal formalities that unsophisticated insureds are unlikely to understand. "[A]n outside reader may have an illusion of understanding, but only knowledge of the subsequent case law and regulatory actions can reveal what the language means in the eyes of the law. ${ }^{\prime 142}$ Insofar as the semantic priority of construction operates to give words, phrases or entire clauses conventional legal meanings that significantly diverge from their nonlegal meanings, it can also function to mislead unsophisticated parties.

Although contract scholars have written a great deal about the advantages and disadvantages of plain meaning rules - what one might call "interpretive formalism" - they have paid less attention to the potential utility and possible downsides of formalities - what might be called "noninterpretive formalism." ${ }^{143}$ We do not have a general theory of when formalities add value, of their optimal design, or of how to generate new formalities. Such a theory would assess inter alia the costs and benefits of the production of formalities through acts of judicial construction and section 211(2) in various types of contracts. Such a theory is beyond the scope of this work. For present, it is enough to observe the phenomenon and the potential semantic priority of acts of judicial construction.

\subsection{Rules of Construction and Pragmatic Priority}

Although the application of a formalistic altering rule does not itself require interpretation, the rule itself can give words new conventional meanings. Construction is semantically prior to interpretation when individual acts of judicial construction generate new formalities, which is to say, when they produce new formalistic altering rules.

The pragmatic priority of construction, in distinction, appears in the interpretation of certain legal acts. It follows from the fact that parties often take rules of construction into account when choosing their words. When this is so, on order to identify the parties' communicative intent-the pragmatic meaning of their words-one needs to know something about the altering rule they mean to satisfy.

Consider the communicative intent of the following provision in a negotiated written agreement between sophisticated parties:

This instrument embodies the whole agreement of the parties. There are no promises, terms, conditions, or obligations other than those contained in this contract, and this contract shall supersede all

$142 / d$

${ }^{143}$ Ian Ayres is an exception. See Ayres, supra note 4 at 2080-83. 
previous communications, representations, or agreements, either verbal or written, between the parties. ${ }^{144}$

The provision is an integration clause. Without saying so explicitly, it expresses the parties' shared intent that the writing be treated as integrated under the parol evidence rule, with the legal effect of excluding extrinsic evidence of contrary or additional terms. As discussed above, the parol evidence rule is a type of altering rule. It allows parties to change the default rules of construction that apply to their agreement. Familiarity with that altering rule is essential to identifying the communicative intent of such an integration clause.

I call this the "pragmatic priority" of construction. Construction is pragmatically prior to interpretation when a speaker intends her speech act to satisfy, to conform to, or to avoid a rule of construction. When this is the case, one cannot identify the pragmatic meaning of the speaker's words or actions without knowing something about that rule of construction.

The pragmatic priority of construction is integral to formation rules that require that parties intend legal liability. Recall the rule for preliminary agreements: a preliminary agreement creates a duty to negotiate only if the parties intended it to be legally binding. Such an intent presupposes a rule of construction that gives that intent legal effect. Its interpretation therefore also presupposes awareness of that rule of construction. The rule of construction is pragmatically prior to the intent to effect a legal change.

Intent-to-contract rules are the most obvious, but by no means the only examples of the pragmatic priority of construction. Contractual agreements between sophisticated parties often include clauses intended to effect one or another legal change. In addition to integration clauses, examples include warranty limitations and non-reliance clauses; material adverse change clauses in merger or acquisition agreements; provisions in consumer contracts that permit unilateral modification with notice; remedial clauses such as damage limitations or liquidated damages clauses; and choice of law, choice of forum and arbitration clauses. In order to identify the communicative intent of any such clause-in order to interpret its pragmatic meaning-one must know something about contract law.

More specifically, one must know that there perhaps exists an altering rule that the parties' intend their words to satisfy. ${ }^{145}$

The above examples involve contractual agreements that aim to achieve specific legal effects. Rules of contract construction can also figure more globally into how parties speak. Legal actors often choose their words in light of the legal rules they expect to determine their legal effect.

Williston suggests an example.

${ }^{144} 1$ A Williston on Contracts 4th Forms $\S 33 \mathrm{~F}: 2$ (2016).

145 "Perhaps exists" because the parties might intend to exercise a power they do not have. 
In an ordinary oral contract or one made by correspondence, the minds of the parties are not primarily addressed to the symbols which they are using; they are considering the things for which the symbols stand. Where, however, they incorporate their agreement into a writing they have attempted more than to assent by means of symbols to certain things, they have assented to the writing as the adequate expression of the things to which they agree. ${ }^{146}$

Williston posits here that when parties agree to an integrated writing, they expect it to be construed according to its plain meaning, and that their communicative intentions and choice of words presuppose that rule of construction. As an argument for the plain meaning rule, this suffers from circularity. Because sophisticated parties' expectations depend on what the legal rule is, those expectations cannot serve as a reason to choose one rule over another. But as an analysis of parties' communicative intentions when contracting in the shadow of a plain meaning rule, it reveals an important truth. Sophisticated parties take rules of construction into account when choosing how to speak. ${ }^{147}$ The interpretation of their communicative intentions - of the pragmatic meaning of their words and actions-also must take account of the salient rules of construction and their effect on what those parties say and do.

Public law theorists have recognized something like the last point. William Eskridge and John Ferejohn's anticipation-response theory argues that legislators and legislative staff often anticipate judicial construction of the legislation they produce, and that committee reports and floor debates should be interpreted accordingly. ${ }^{148}$ And John McGinnis and Michael Rappaport have argued for an "original methods originalism" that would take account of the rules of constitutional construction in effect at the time of the Constitutional Convention and subsequent ratification, on the theory that the framers and ratifiers would have themselves taken those rules into

${ }^{146} 2$ Williston (1st ed.) $\S 606,1165$.

${ }^{147}$ The same observation lies behind familiar arguments, often advanced by those who employ economic analysis, that plain meaning rules give parties a new reason to invest in expressing their intentions in clear language. See, e.g., Schwartz \& Scott, supra note 48 at 572. It is also appears in Jody Kraus and Robert Scott's idea of intended contractual means, as distinguished from contractual ends. Jody S. Kraus \& Robert E. Scott, Contract Design and the Structure of Contractual Intent, 84 N.Y.U. L. Rev. 1023, 1026 (2009). ${ }^{148}$ See Victoria Nourse, A Decision Theory of Statutory Interpretation: Legislative History by the Rules, 122 Yale L.J. 70, 143-47 (2012) (discussing William N. Eskridge, Jr. \& John Ferejohn, The Article I, Section 7 Game, 80 Geo. L.J. 523 (1992)). 
account when they assigned meaning to the constitutional text. ${ }^{149}$ More generally, because public lawmakers intend their words to effect a legal change, lawmakers are likely to chose them with some attention to the rules of construction that secure that effect. One might therefore expect the pragmatic priority of construction to be ubiquitous in public law. ${ }^{150}$

The situation is different in the law of contracts. Although rules of construction are sometimes pragmatically prior to contract interpretation, they are not always so. The question is an empirical one and depends both on the rule of construction at issue and on the responsiveness of legal actors to it. Consider the UCC rule for express warranties:

Any affirmation of facts ... which relates to the goods and becomes part of the basis of the bargain creates an express warranty. . . It is not necessary to the creation of an express warranty that the seller use formal words such as 'warrant' or 'guarantee' or that he have a specific intention to make a warranty. ${ }^{151}$

An "affirmation of fact" is not a legal act, and might be made without any awareness of the legal consequences. The requisite altering act does not presuppose awareness of the altering rule. More generally, though contracting parties often intend the legal effects of their words, many contract altering rules do not require such an intent. Corbin suggests another helpful example, involving formation rules.

${ }^{149}$ John O. McGinnis \& Michael B. Rappaport, Original Methods Originalism: A New Theory of Interpretation and the Case Against Construction, 103 Nw. U.L. Rev. 751 (2009).

${ }^{150}$ That said, even in the context of public lawmaking responsiveness to relevant rules of construction is a question of fact. A legislator might know that she is making a law without knowing all the rules of construction that will determine the legal effects of her words and actions. Victoria Nourse has argued, for example, that "[t]here are good empirical reasons to believe that members of Congress are indifferent to the vast majority of ordinary statutory interpretation cases in appellate courts." Nourse, supra note 148 at 144. And several studies by Abbe Gluck and Lisa Bressman indicate that the congressional staffers who write federal legislation do not fully understand the cannons of statutory interpretation and construction courts will use to give legal effect to the statutes they draft. Abbe R. Gluck \& Lisa Schultz Bressman, Statutory Interpretationfrom the Inside- An Empirical Study of Congressional Drafting, Delegation, and the Canons: Part I, 65 Stan. L. Rev. 901 (2013). Even in public lawmaking, legal actors only sometimes take rules of construction into account when choosing their words.

${ }^{151}$ U.C.C. $\S 2-314(1)(a) \&(2)$. 
There seems to be no serious doubt that a mutual agreement to trade a horse for a cow would be an enforceable contract, even though it is made by two ignorant persons who never heard of a legal relation and who do not know that society offers any kind of a remedy for the enforcement of such an agreement. ${ }^{152}$

Because the rules of contract formation do not require that parties intend or expect the legal consequences of their acts, parties can enter a contract without intending to do so. In such cases, their communicative intentions do not incorporate the altering rules that give their words legal effect. When parties do not intend or expect a legal change, interpreting their communicative intent does not require an understanding the relevant rule of construction.

Acts of public lawmaking are juristic acts, or what German private law calls "Rechtsgeschäfte" in civil law contexts. ${ }^{153}$ A juristic act is a speech act that expresses the speaker's or author's intent to effect a legal change by the very expression of that intent. ${ }^{154}$ Thus the pervasive pragmatic priority of authorizing rules - or rules of construction-in acts of public lawmaking. The communicative content of juristic acts includes the intent to effect a legal change, and therefore to satisfy an altering rule. The acts that generate and alter contractual obligations, in distinction, need not be juristic actsthough they sometimes are. Rules of construction are only sometimes pragmatically prior to contract interpretation, but not always and not pervasively. ${ }^{155}$

1521 Corbin (1st ed.) $\S 34$ at 135 . The Second Restatement suggests another example:

A orally promises to sell $B$ a book in return for B's promise to pay $\$ 5$. A and B both think such promises are not binding unless in writing. Nevertheless there is a contract, unless one of them intends not to be legally bound and the other knows or has reason to know of that intention.

Restatement (Second) of Contracts $\S 21$ ill. 2 (1981)

${ }^{153}$ The idea of a juristic act is relatively unfamiliar in contemporary AngloAmerican legal theory, but is important enough in German private law that Werner Flume gives it a full volume of his four volumes on the German Civil Code. Werner Flume, 2 Allgemeiner Teil des Bürgerlichen Rechts: Das Rechtsgeschäft (1992). The category of juristic acts is central to Wigmore's account of the parol evidence rule. 5 John Henry Wigmore, A Treatise on the Anglo-American Law of Evidence in Trials at Common Law, § 2401, 238 (2d ed. 1924) (describing the category of "jural acts").

${ }^{154}$ For more on juristic acts, see the discussion of power conferring rules in Gregory Klass, Three Pictures of Contract: Duty, Power and Compound Rule, 83 N.Y.U. L. Rev. 1726, 1740-42 (2008).

${ }^{155}$ For more on this point, see $i d$. (passim). 
Although a complete theoretical account of the semantic and pragmatic priorities of construction is fairly complex, each reflects a familiar fact: authoritative judicial decisions can give words new legal meanings, and legal actors often take into account the legal effects of their words and actions when deciding what to say or do. When either happens, construction can figure into the meaning of legal actors' words and actions. Interpretation must take account of both any acts of construction that give words conventional legal meanings (semantic priority) and the rules of construction that the legal actors might have in mind (pragmatic priority). Another way of putting this is that construction is not exogenous to meaning. It does not stand outside of legal actors' intentions or the language they use.

\section{Conclusion}

In order to understand how contract law translates parties' words and actions into legal obligations, permissions, powers and other relations, it is important to distinguish two activities: interpretation, which is the determination of the meaning of the parties' words and actions, and construction, which determines their legal effect.

Interpretation is the application of the interpreters' linguistic abilities and social knowledge to identify the meaning of parties' words and actions. There are, however, multiple types of meaning, and therefore multiple types of interpretation. Depending on the facts of the transaction and the legal question, the existence or content of a contract might turn on the plain meaning of a writing, on the contextually determined use meaning of the parties' words and actions, on subjective or objective meaning, on the purpose of the agreement or a term in it, or on the parties' beliefs and intentions. Contract interpretation can involve the identification of any of these types of meaning.

Which type of meaning is legally relevant when depends on the applicable rule of construction. More specifically, it turns on the relevant altering rule. Altering rules specify who must do what to effect a legal change. Interpretive altering rules require that parties say or do something with the right meaning. Interpretation enters the contract exposition through interpretive altering rules.

But not all contract altering rules look to the meaning of the parties' words and actions. Formalistic rules condition legal outcomes on acts of the right form, without regard to their nonlegal meaning.

Although interpretation precedes construction in the order of exposition, there are three other senses in which construction can be prior to interpretation. First, legal interpretation always serves construction. What counts as the correct approach to interpretation therefore depends on the 
applicable rule of construction. Second, individual acts of construction, including the application of interpretive altering rules, can in our system produce new legal formalities. Acts of construction can thereby give words new semantic meanings. Finally, because contracting parties act in the shadow of the rules of construction that will give their actions legal effect, it is sometimes impossible to understand the meaning of what they say and do without knowing something about the altering rules they intend to satisfy or avoid. This is the pragmatic priority of construction.

This Article's approach has been descriptive and analytic. I have not discussed when the contract law should attend to one or another type of meaning or the factors that go into choosing one or another interpretive approach. Nor have I examined the costs and benefits of adding formal components to interpretive altering rules, the choice between interpretive and formalistic altering rules, or how the law should go about recognizing new formalities. These design questions are important. But before addressing them, one must be have a clear understanding of the toolkit lawmakers have at their disposal. That has been the project of this Article. 